





\section{The First Century of \\ The John Carter Brown Library}





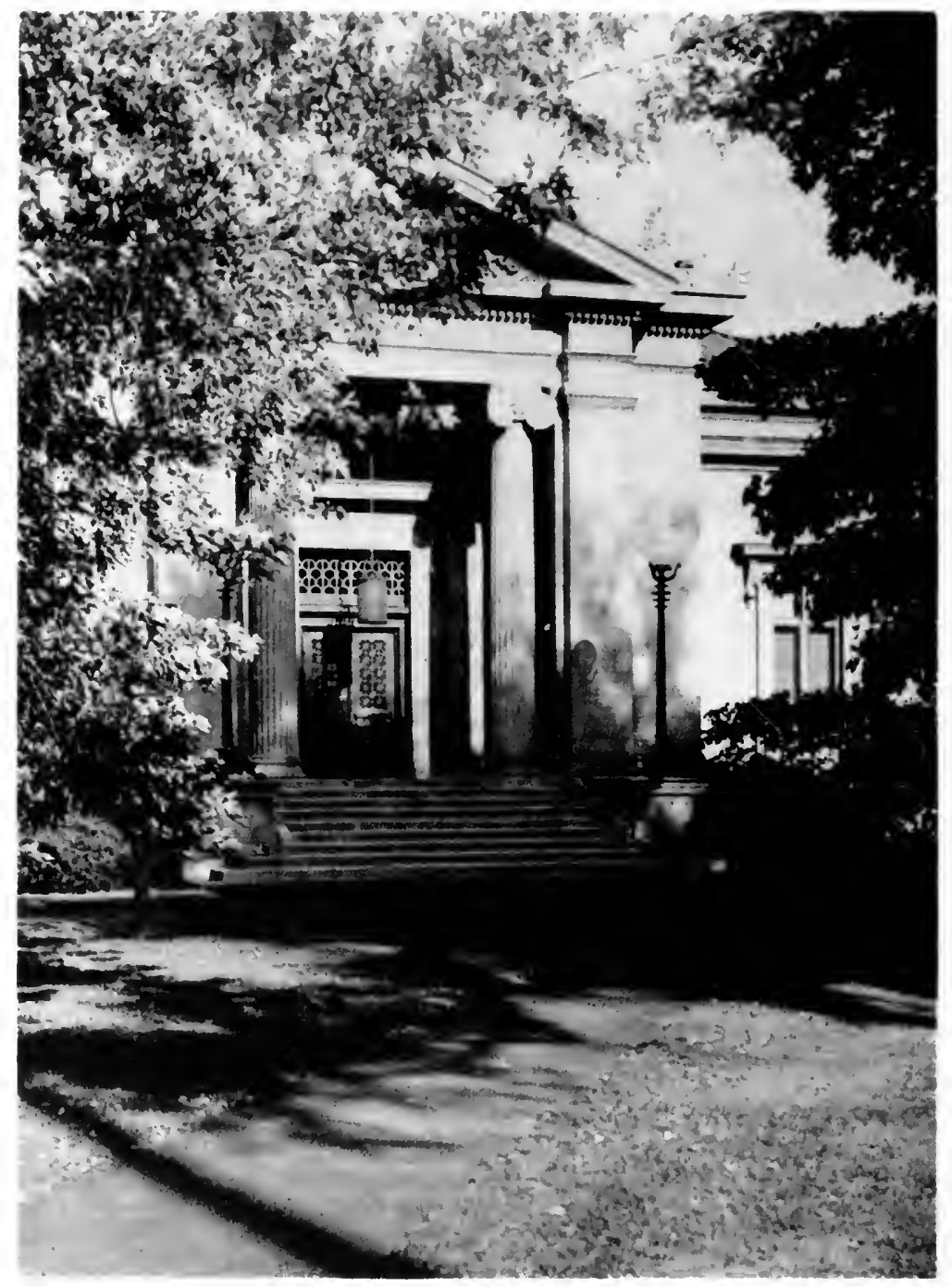

THE LIBRARY BUILDING

Dedicated 1904 
$B b$

W

\title{
THE FIRST CENTURY OF THE
}

John Carter Brown Library

A History with a Guide

to the Collections

\author{
BY \\ LAWRENCE C. WROTH
}

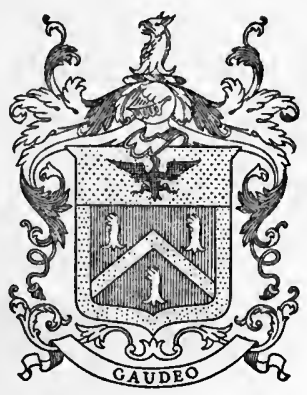

PROVIDENCE, RHODE ISLAND

The Associates of The JohN Carter Brown Library MDCCCCXLVI 
D. B. UPDIKE - THE MERRYMOUNT PRESS - BOSTON 


\title{
The Contents
}

\author{
Part I \\ A Century of Purpose
}

A Brief History of the Library

Part II

An Analysis of the Collections

Pre-Discovery Science and Geography

The Period of Discovery and Exploration, 1492-1550 24

The Empires of Spain and Portugal-Mexico, the West

Indies, Peru, and Brazil

Florida and the Southeast of the United States 29

The Spanish Southwest $\quad 30$

New France, Louisiana, and the French West Indies 31

The Dutch and Swedes in America 35

The British Colonies of North America and the West Indies

The Revolution $\quad 39$

The Constitution $\quad 42$

The Western Expansion 43

The Native Languages of America $\quad 45$

The Press in English North America 47

Church History and Doctrine $\quad 49$

The Map Collection $\quad 50$

Voyages and Travels 54

The Far North $\quad 56$ 
vi

The Contents

Economics $\quad 59$

Science $\quad 63$

Law and Government $\quad 66$

Bibliography $\quad 69$

The Manuscript Collections of American Source Materials $\quad 71$

Illuminated Manuscripts, Incunabula, Bibles, Aldines, and other non-American Collections

Part III

The Work of the Library

The Bibliographical Study of the Collections 79

Service to Local and Visiting Students 82

Service through Correspondence with Distant Students 82

Exhibitions and Addresses $\quad 83$

Publication and Photographic Service 84 


\section{Part I}

A Century of Purpose, a Brief

History of the Library 


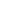




\section{The Beginning of the Collection}

F the John Carter Brown Library were to plan a memorial 1 celebration of its founding, a difficulty would arise in choosing between a centennial and a bicentenary. The records of the Library show that in the year 1846 John Carter Brown, a merchant and manufacturer of Providence, then in his fiftieth year, began systematically to accumulate the library which now, as a semi-public institution, is called by his name. But even though 1846 may be regarded as a most significant date in the Library's history, it is a fact that there is in the collection a book relating to the history of America in which are written the name of John Carter Brown as owner and the year 1808 as the date of acquisition. Furthermore, if there may be counted the American books which descended to the institution from the library shelves of the first two Nicholas Browns, a much earlier date than this might be chosen as marking the beginning of the collection. There is one book in the Library in which the first Nicholas wrote his name at the age of eleven years in the year 1740; there are others which he is thought to have bought in 1769 ; and still others which he and members of his family acquired between that year and the end of the century. If, therefore, the institution is to be regarded as the continuation of the Brown family library, it is reasonable to say that today it has reached and passed its bi-centennial year of existence.*

\footnotetext{
- For the basis of the historical sketch which forms the first section of the present work, the author is indebted to The John Carter Brown Library. A Hisiory, an account of the institution in which George Parker Winship, its former librarian, described with ripe and intimate knowledge the development of the collection and its establishment as a semi-public library. In a briefer form this historical section has appeared as The John Carter Brown Library in Brown University, the author's contribution in 1936 to the series of charming little books on Rhode Island libraries published through the interest of Eugene A. Clauss, of Providence.
} 
John Cartér Brown and his brother Nicholas were sons of the second Nicholas Brown, the Providence merchant whose benevolence to the discouraged Rhode Island College in 1804 resulted in the change of name of that institution to Brown University. After their graduation from college in 1816 and 1811 respectively, the two young men began collecting books in the approved fashion of their day, making occasional purchases in the fields dear to the early nineteenth-century amateur, acquiring fine copies of the Greek and Latin classics, Bibles notable for their monumental typography, sumptuous editions of celebrated works of literature, volumes boasting extra-wide margins and "embellished" with copperplate illustrations, and various other productions of the sort that filled the dreams of the old-style collector, the Dibdinian bibliomaniac. Now and then one or the other of the brothers bought a book or pamphlet of American interest, but before 1840 neither of them could be regarded as a specialist collector of Americana. In 1846 Nicholas Brown went to Rome as United States consulgeneral, detaching himself. for years thereafter from his Providence interests. John Carter bought his American books and added them to his own collection. It has been said that this fortuitous happening decided the course of his future collecting, but there are facts which show that the determination on his part to form an American library had come into being months, or maybe years, before this occurrence. Certainly as early as 1845 he had made plans for the large-scale acquisition of Americana which, continued by him for twenty-nine years, resulted in the formation of his distinguished collection. What the determining factor was in his change from general to special collecting is not certain, but it is clear enough that sometime in the early 
1840's his aims and his whole attitude towards his hobby underwent a radical change. A warm and zestful interest in the new pursuit replaced his earlier half-heartedness of purpose in the formation of a "gentleman's library."

Emphasis upon the dates mentioned in connection with the beginnings of John Carter Brown's collecting is justified because those dates provide one explanation of the degree of completeness the Library has attained in many of its departments. There is no virtue in age of itself, but continuity and steadily maintained purpose are excellent things in the formation of book collections. Inevitably libraries possessing these attributes are made up of books and groups of books which newer institutions must seek in vain.

\section{A Policy Established}

W HEN John Carter Brown began making his American collection, whether we fix the year of his beginning as 1808 or 1846 , the year 1800 seemed to him little earlier than yesterday. Events of a date later than the end of the century had occurred within his own experience and, therefore, in his view were the raw material of history rather than history itself. Interested in the sources from which the American political and social institutions of his own day had derived, he set the concluding year of the eighteenth century as the outside limit of his field of collecting. Throughout the Library's changes of status as the possession of two later private owners and of Brown University, that boundary, though for reasons different from those which moved Mr. Brown, has never been changed. Long experience has shown that the term of years between the discovery of America in 1492 and the end of the Federalist regime in the United States in 1800 is so extensive in point of time, so 
varied in its problems, events, and interests that it is all but impossible for any single institution to cover it as fully as should be done. No one has yet attempted a calculation of the actual number of books of American interest that came from the presses of the world in that period of three hundred and eight years, but we in the Library know from daily experience with bibliographies and booksellers' catalogues that our 25,000 or more titles printed before 1801 represent but a fraction of the whole. We know, too, that the financial resources of few if any of the world's libraries would be great enough to enable them to buy everything currently offered from that period. With these facts before us we realize clearly that our book funds would be spread very thin indeed if we entered the immensely broader field of the later centuries. On this account we have maintained the policy of restriction adopted by John Carter Brown in the beginning of his collecting, concentrating our efforts upon source books of American history printed before 1801 and referring the investigator to the well-rounded collections in the general library of Brown University for books of the later period.

\section{The Contemporary Background}

$\mathrm{B}^{\mathrm{UT}}$ let us go back for a moment to the romantic early days $\mathbf{B}_{\text {of the Library's formation. A few months before John }}$ Carter Brown bought the collection of his brother Nicholas, he came in touch with a young Yale graduate who was about to enter upon what turned out to be a notable career as a bookseller and as a writer upon themes related to American history. This was the individual who in later years styled himself "Henry Stevens of Vermont," and, satirizing the custom of contemporary pundits, placed after his name upon 


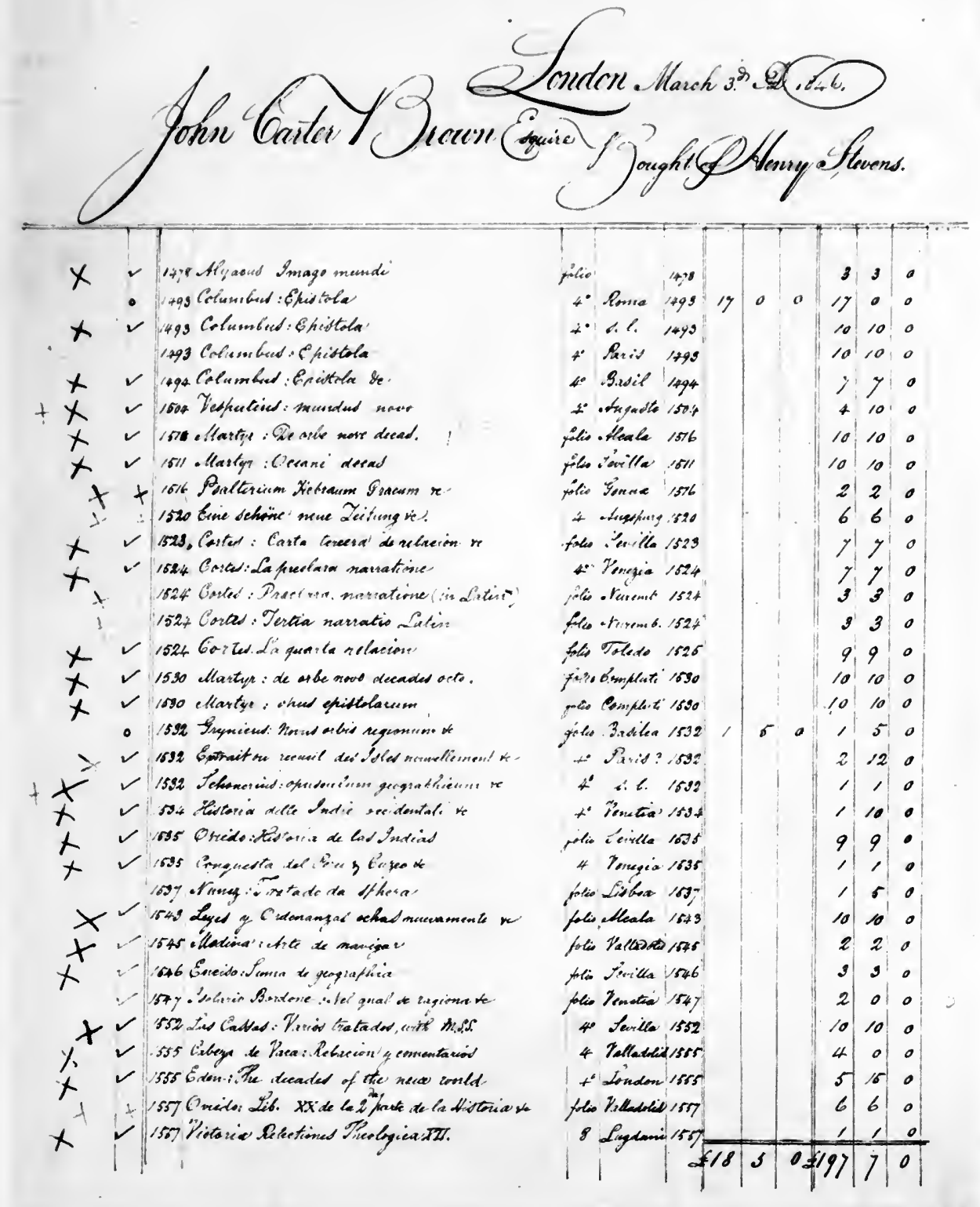

Invoice of the earliest shipment of books from Henry Stevens of Vermont to John Carter Brown in 1846. 

the title-pages of his books various initials which would have been mysterious even to his associates if he had not in many cases obligingly written out their meaning. In the absence of such aids to the imagination, a reader might conceivably guess that G.M.B., in its Vermont context, meant "Green Mountain Boy," but only one of extraordinary discernment would have a suspicion that the initials "B.B.A.C." proclaimed that Mr. Stevens had been "Black Balled Athenæum Club," an incident of the sort that less robust souls usually take pains to conceal. After visiting him in London in 1856, Nathaniel Hawthorne described him as "a kindly and pleasant man" engaged in a sort of "book-brokerage," and later designated him the "American man of libraries." But all this was still to come when young Stevens agreed with John Carter Brown and several other collectors to go to England on their behalf in search of rare books of American interest. That was in 1845 , and except for occasional visits on business the Green Mountain Boy never returned to the land of his birth. His son, Henry Newton, and grandson, Henry, have succeeded him in the business he set up in England, and today the firm of Henry Stevens, Son \& Stiles, dealers in Americana, is an honored London institution which has reached its hundredth year of service to English and American libraries and collectors.

Those were great days and London a great place for the collector of Americana. Neither the private libraries of Great Britain nor the shelves of her antiquarian book shops had yet been thoroughly searched for English books relating to America. On the continent only a few collectors had specialized in books of New World interest. But a new era was about to begin. Many years before the departure of Henry Stevens for London, Obadiah Rich, an American 
consul in Spain, had begun collecting the Spanish and other early works on America still easily to be picked up in the country of his residence. A successful buyer, he was able by 1829 to pack his boxes with this new wealth of the Indies and, carrying them to London, turn bookseller. In 1832, 1835 , and 1844 he issued catalogues so filled with works of importance in the study of America as to serve almost as bibliographies of the subject. Furthermore, there had been printed in Paris in 1837 the Bibliothèque Américaine of Henri Ternaux-Compans, a work which was virtually the catalogue of this distinguished French collector's library. When Stevens reached England in 1845 many of the Rich books were still available for purchase and the Ternaux collection had recently come upon the market. It is possible for one familiar with the John Carter Brown Library of today to pass before its shelves and point to this book and that, identifying each of them as a Rich book or a Ternaux book transferred to the ownership of John Carter Brown through the zeal and inspired antiquarianism of young Henry Stevens.

Collectors of Americana in this country were few then and in the ensuing twenty-five or thirty years. There were first of all James Lenox, of New York, and John Carter Brown, of Providence. There were also at that time George Brinley, of Hartford, in some ways the greatest of them all, Peter Force, Thomas Aspinwall, James Carson Brevoort, Henry C. Murphy, and Samuel Latham Mitchill Barlow. Sharp though it became at times, the competition among these collectors was still confined within reasonable price limits. It was only in later years that the pleasant field of Americana collecting became a battleground. The word "Americana" as a designation of the source materials of American history and life had hardly come into use. Henry 


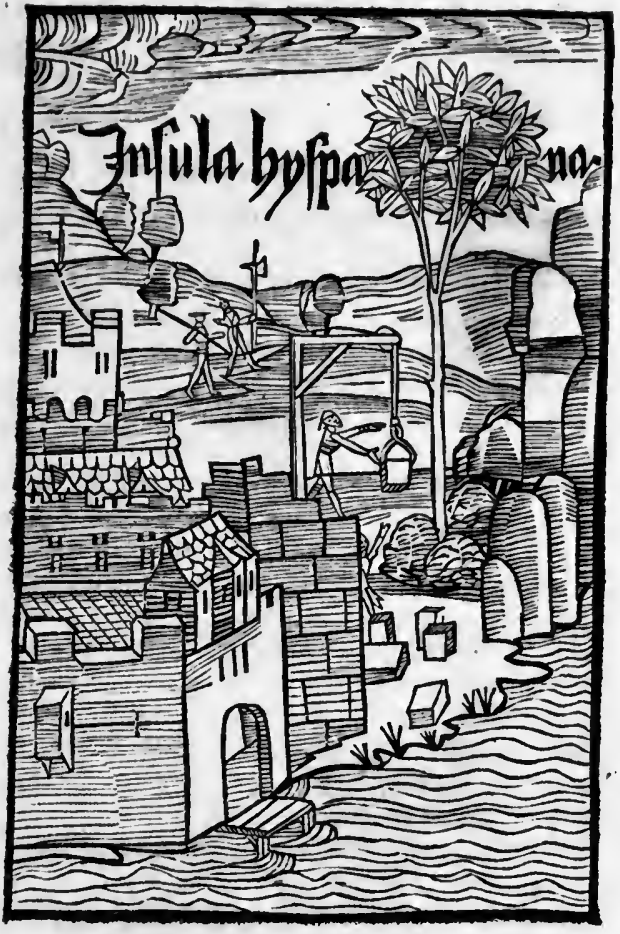

Building the "tower and fortress" at La Navidad on Hispaniola. The woodcuts in the Columbus "Letter" of Basle, 1493, are the earliest pictures relating to America. 
Harrisse had not yet published his Bibliotheca Americana Vetustissima, nor had Joseph Sabin begun to compile his great Dictionary of Books relating to America. That was truly the age of innocence for bookseller and collector alike. The consequence of their relative unawareness was that the libraries of John Carter Brown and James Lenox were founded at a cost which, in retrospect, moves the presentday collector to something like tears of regret for a day that is gone. Ordinary books for which today we pay in pounds were bought by those early collectors for an equal number of shillings, while books of unusual interest have advanced in price by a very much greater ratio than this of twenty to one. In $1846 \mathrm{Mr}$. Brown bought for ten guineas the second Latin edition of the letter in which Columbus announced the discovery of America, a little book printed at Rome by Stephan Plannck in 1493. A copy of that foundation book sold today would bring its owner in the neighborhood of one hundred times as much. For the same amount in the same year he procured a copy of one of the three Paris editions of the Columbus letter, an edition known today in only three specimens all told. Many times since then his successors in the task of building up the Library have paid large sums for books which he declined to buy as too dear at a few dollars. But enough of this! The purpose of mentioning these details of price history is not to drive the modern book buyer to despair but rather to show at how much less expense the mid-nineteenth century collector might create a library of consequence than may be done by his equally ambitious brother of today. 


\section{The Collection Takes Form}

T $^{\mathrm{T}}$ was not until 1866 that the collector of Americana knew 1 exactly what he was doing in purchasing a book of the early period. In that year was published the Bibliotheca Americana Vetustissima, a bibliography by Henry Harrisse, which listed and described all discoverable books relating to America published through the year 1550. These books, of course, were the fundamental printed sources for the periods of discovery and exploration. Not only did the study of the "B.A.V.," as Harrisse's book soon came to be designated, fix certain definite aims in collecting, but because "book openeth book" it led to a general broadening of conception of the whole subject. In 1868 began the publication of Sabin's Dictionary of Books relating to America, a great work of reference for historian and collector which was brought to a conclusion only in 1936 after seventy years of labor, often interrupted, on the part of three successive editors. There occurred also the publication of such special bibliographies as G. M. Asher's A bibliographical and historical Essay on the Dutch Books and Pamphlets relating to New$\mathcal{N}$ etherland, and, almost too late to be of use to John Carter Brown, Thomas W. Field's Essay towards an Indian Bibliography. In the same period there were issued the Americana catalogues of certain learned booksellers, for example, those of Maisonneuve of Paris, Stevens of London, and Frederik Muller of Amsterdam. These varied works gave a surer guidance to the collector than he had previously possessed and opened fields to him which before he had hardly dared enter. It was a natural boldness of disposition supported by the exact knowledge which learned specialists were now providing that led Mr. Brown, in a day when 
most collectors were confining themselves to narrower fields, to establish the geographical scope of his collection as the entire Western Hemisphere. American history, in his scheme, was an intellectual entity resting upon the records of all the Americas, including Greenland and the Arctic, from the Discovery to the year 1801. An additional factor of interest in his collecting was his realization that underlying the discovery of America were the geographical ideas of the ancient and mediaeval worlds, and that tied up with its exploration was the development of the science of navigation. In both these fields of knowledge he sought and found for his library many notable works which are of interest to the student of American history even though the name America, for the best of reasons, is not to be discovered between their covers.

Another advantage possessed by John Carter Brown in the formation of his library was the learned guidance of John Russell Bartlett of Providence, his friend and occasional librarian. Mr. Bartlett was a man of versatile scholarship and broad experience. Philologist, author, bookseller, artist, and anthropologist, he was at one time United States Commissioner for determining the Mexican boundary and later held office as Rhode Island's secretary of state. His influence upon the development of the collection is felt to this day. It was through him that Mr. Brown became interested in the collecting of works of native American linguistics, of works on the Spanish Southwest of the United States, and of books and lesser publications that issued from the presses of Mexico and Peru in the sixteenth century-special fields hardly known to Mr. Brown's contemporaries among American collectors, and all of them fields in which the Library today is actively helpful to bibliographers and historians. 


\section{The Second Generation}

TOHN CARTER BRown, the founder of the Library, died in 1874. When the second printed catalogue of his books, edited by Mr. Bartlett, was published in the years 18751882 , the collection numbered some 7,000 titles of books published before 1801. In comparison with the 25,000 titles from that period in the Library today, or with the large number of American titles of all periods in other modern libraries, that seems a small collection. When it is understood, however, that its component books represented in large measure the foundation narratives upon which has been reared the structure of New World history, one realizes that the importance of the collection which Mr. Brown had formed was out of all proportion to its size.

The transfer of the Library at the death of its founder to the hands of his widow, Sophia Augusta Brown, is a circumstance which explains a certain anomaly in the constitution of the collections. It is often commented upon that this institution, distinguished for its collection of Americana, is also widely known for the possession of certain celebrated books and manuscripts that have no bearing whatever upon its main interest. This state of things is explained by the fact that Mrs. Brown was interested hardly at all in Americana but very much interested in fine books. It is no exaggeration, indeed, to say that she was interested only in the finest of fine books, and to assert that each of the books she acquired for the collection, whether an illuminated manuscript, a specimen of fifteenth-century printing, or a Shakespeare first folio, was in the form of a copy specifically known to collectors for beauty or importance, or, indeed, for both these qualities with the added virtue of extraordi- 
nary condition. These volumes were chosen by Mrs. Brown under the guidance of John Russell Bartlett, who retained his interest in the Library after the death of its founder, and of Frederick S. Ellis, a scholarly English bookseller in whose judgment she safely, as the event proved, placed complete confidence. It was her feeling that books of this character gave to the family library the decorative quality and the broad cultural aspect lacking, to a certain extent, in the general run of books on America.

But the chief service of Mrs. John Carter Brown to the Library was the interest in it she stimulated and maintained in the minds of her two sons, John Nicholas and Harold. The younger of these, like his mother, was only mildly interested in Americana, and, like her again, he followed his personal preferences and formed a small but admirably chosen collection of books on the liturgy of the Church of England and the history of that church in what is now the United States. Upon his death in 1900 this collection became part of the present John Carter Brown Library. In the intervening years it has been much enriched by his widow, Mrs. Harold Brown, of Newport, and by his nephew, the second John Nicholas Brown. Shelved in the Library building in the "Harold Brown Room," it forms the nucleus of a group of works pertaining to the history and tenets of all religious bodies existing in the colonial period in British America.

\section{The Growth of an Idea}

OHN NichoLAS, the elder son of John Carter Brown, inherited the interest of his father in the Americana library. As little more than a boy, in the course of the family's long residences in Europe, he began purchasing important books 
for the collection with a quality of judgment that never deserted him. In his letters to John Russell Bartlett, he refers frequently to the Library, more in earnest than in boyish jest, as "La Grande Bibliothèque." Already he was beginning to think of it as something more than a cherished family possession. It has been said that in the long run his chief service as a collector for the Library was the care he gave to searching out fine copies of books that his father, in the haste of his early collecting, had procured in imperfect or defective specimens. We should underestimate his achievement, however, if we failed to recognize that in addition to this service to the Library he strove successfully to secure for it scores of important books which for one reason or another his father had never been able to acquire, some of them-the Charles V Agnese Atlas, the Maggiolo Atlas, and the Champlain Journal, for example-of the highest repute among collectors and historians throughout the world. He increased the value and importance of the Library in another sense by consistently employing for the preservation and decoration of some of its notable volumes the finest binders of his time, particularly the celebrated Frenchmen -Cuzin, Mercier, Thibaron-Joly, and Chambolle-Duru. The general value of the collection from the bookman's standpoint was very much improved by his fastidious desire for the perfect copy; its appearance was rendered distinctly more noteworthy by his demand for the best in binding and decoration.

It was in the year 1898 that Mrs. John Carter Brown made over to John Nicholas Brown, by deed of gift, the library of his father. The new owner determined at once to erect a building for the safekeeping of a collection which by this time he looked upon as a public trust. Well known 
in Europe and America through its printed catalogues, the Library had become what may be correctly described as "celebrated" through the publication in 1889 of Justin Winsor's Narrative and Critical History of America. Mr. Winsor's innumerable footnote references to works in the "CarterBrown" Library had impressed upon scholars everywhere the richness of the collection. Its new owner had employed in 1895 a full-time librarian; now in 1898 he proposed to organize the private library of his family as a public institution of permanent usefulness. Before the building planned to hold the collection had been begun, however, John Nicholas Brown died, leaving the books, an endowment of $\$ 500,000$, and a building fund of $\$ 150,000$ in the hands of trustees with power to place the Library where they should deem best. In 1901 these trustees gave the Library to Brown University under a deed of gift which embodied instructions found in the will of the donor. These were, in brief, that the Library was to occupy its own building and was to be separately administered by its own staff under the direction of a Committee of Management, appointed by the Corporation of the University. The endowment was to be used for the maintenance of the institution and for the addition of books to its collections. The gift was accepted by Brown University, and when, on May 17th, 1904, the building was opened for use, the career of the John Carter Brown Library as a semi-public institution was begun.

The death of the donor of the Library and of his brother Harold within a week of each other in the spring of 1900 removed from the ranks of American collectors two seriousminded, cultivated young men who were carrying on the best tradition of American life. Some years later, on the occasion of the one hundred and fiftieth anniversary of the 
founding of Brown University, the Vice-Chancellor of the University of Manchester said in his congratulatory address that through the connection of four generations of the Brown family with the college, particularly in the establishment of the John Carter Brown Library, "America has given to Europe an example of the handing on of a great tradition of beneficence, which is one of the truest marks of aristocracy."

\section{An Institutional Library}

7 HE institution thus formed was fortunate in that George 1 Parker Winship, who had come to it in 1895 as Mr. Brown's librarian, was retained as its executive head under its new status as a semi-public library. Trained in research and in the uses of bibliography, Mr. Winship quickly expanded the scope of the Library's interests and put it actively to work for American scholarship. Sensitive to the traditions and standards of the Library as they had taken form under its private owners and its former learned librarian, he carried on those traditions and made those standards its rule of operation. When he resigned the librarianship in 1914 his bold and intelligent collecting had more than doubled the size of the Library and had added to its resources a considerable number of books and maps of the highest individual importance. Mr. Winship's successor in the librarianship was Champlin Burrage, an American scholar of English training, learned in the classics and in the history of English and American sectarianism. Through Mr. Burrage's knowledge of letters many interesting additions were made to the Library's collections. After his retirement in 1916 to resume the teaching of the classics, Worthington Chauncey Ford served for six years as acting librarian. In 
that period Mr. Ford, a distinguished historian and student of American source material, especially in the field of manuscripts, carried through the publication of four parts of a printed catalogue and brought the Library actively into cooperation with the Massachusetts Historical Society in its notable plan for the republication by photostat facsimile of rare American books and pamphlets. The present librarian, Lawrence C. Wroth, was appointed in 1923.

The successive librarians just named have worked in the closest coöperation with a Committee of Management of which the members have been vigilant and interested stewards of the materials committed to their care by the Corporation of the University. The first committee, comprising President William Herbert Perry Faunce, Mrs. Nicholas Brown, Stephen Ostrom Edwards, Robert Hale Ives Goddard, and William Vail Kellen, served without change in membership until the deaths of Mr. Edwards and Colonel Goddard in 1916. In their places were elected Charles Lemuel Nichols and Daniel Berkeley Updike, and since that time the following gentlemen, at different times, have served upon the committee of five which governs the institution: Presidents Clarence Augustus Barbour and Henry Merritt Wriston, John Nicholas Brown, Clarence Saunders Brigham, William Davis Miller, Henry Dexter Sharpe, and, substituting for Mr. Miller through the period of his naval service, Professor James Blaine Hedges.

There were moved to the present building from the library room in the Brown house on Benefit Street 12,000 books. The Library at the present time contains 30,000 books, including its reference materials. This very large numerical increase does not mean that the importance of the collection has been increased in the intervening forty-one 
years in the same proportion. The fundamental works of Americana were, for the greater part, already in the collection when it came into the possession of the University, but since that time a certain broadening of scope has been undertaken by the Committee of Management. The general policy has remained the same; it is still the purpose of the Library to collect, preserve, and make available books relating to the western hemisphere printed before the year 1801 . The evolution of recent thought, however, has to a certain extent affected that policy. It has been recognized with the passage of time that a great light is thrown upon the social and cultural history of a nation, or a community within the nation, by the study of the productions of its press of every sort and on every topic. Alfred W. Pollard, one-time Keeper of Printed Books in the British Museum, impressively phrased the thought that underlies this study of "imprints," that is, of the issues of a particular press or group of presses regardless of subject, when he wrote: ". . . the publication of every book which has issued from printing house or Scriptorium is an event in the spiritual history of the human race, and more particularly in the spiritual history of the country and city in which it appears ..." And the Library has found that its own "imprint" collection, which began to be formed some forty years ago, is a source of great interest to historians and bibliographers. In such a collection, useful for the reflection it presents of the contemporary life of the places concerned, a sermon, a poem, or an advertising handbill is often of as much value to the investigator as a political tract or an account of a battle. A work of fiction, a book of verse, a prayer book, a liturgical work or a hymnal, if printed on this continent within our specified dates, means as much to us potentially as a laborious and learned treatise on a 
specifically American subject. The recognition of these facts has resulted in a broadening of the area of thought and action covered by the Library's collections.

\section{The John Carter Brown "Associates"}

GINCE the time of its establishment as an institution for $S$ the use of the whole community of scholars, the Library has persistently endeavored to make its resources an influence in the development of American historiography. In common with most institutions dependent upon endowment it has found that for several years past the increase in the cost of books and maintenance has paralleled a shrinkage in income. In the past year the Committee of Management became convinced that the solution of the Library's financial difficulties lay in the formation of a group of "Friends," the tested principle of centuries past for the furthering of educational and philanthropic enterprises.

On the evening of January 10, 1944, there came into being at a meeting held in the Library "The Associates of the John Carter Brown Library." The purpose of the organization is to aid in the enlargement of the Library's influence by the increase of its collections, to sponsor important exhibitions of its materials, and to make more widely known through publications its possibilities of service. The direction of the Associates was put into the hands of an executive committee composed of Mr. Wilmarth Sheldon Lewis, of Farmington, Connecticut; Mrs. Jesse H. Metcalf, of Providence; and Mr. Thomas Winthrop Streeter, of Morristown, New Jersey. The Committee of Management is represented on the Committee by Mr. John Nicholas Brown of Providence. Its treasurer is Mr. Harold C. Field, treasurer of Brown University. The first publication of the John Carter 
Brown Associates is now before the reader-this general work on the history of the Library combined with a guide to its collections. The notable additions to its resources made possible by the contributions of the Associates in their first year of existence are described in detail in the Annual Report for the year 1943-1944. All those who have the Library's interests at heart feel that through the formation of this body a new era has been opened in the history of our ancient and distinguished institution. 
Part II

An Analysis of the Collections 



\section{An Analysis of the Collections}

$A_{\text {no more than is found in the foregoing pages about the }}^{\mathrm{N} \text { account of the John Carter Brown Library containing }}$ books composing its collections would be the proverbial performance of Hamlet without the Prince of Denmark. This separate section of our guide, therefore, must be devoted to an analysis of the materials for research in American history brought together upon the Library's shelves in the course of a century of collecting. To single out for mention in this connection a number of exceptional titles would work an injustice upon the Library as a whole. Our analysis, on this account, will be confined to a conspectus of the principal categories which make up the collection, attempting appraisal of each of these by comment based upon experience in their practical utilization and by a statistical comparison of their contents with the totals found in standard catalogues and bibliographies. We begin our description of these categories with a brief account of the scientific and geographical treatises and the compendiums of ancient learning upon which was based the knowledge of the universe possessed by Columbus and his fellows of the late Renaissance.

\section{Pre-Discovery Science and Geography}

THE background against which the new world of America 1 comes into focus in the broad picture of universal history is that provided by the declining Middle Ages and the successive periods of the Renaissance. The student interested in determining how the actors in the drama of American discovery and settlement felt about life and how much or how little they knew of the world about them finds ma- 
terial for his study and reflection in the general historical collections of the John Hay Library of Brown University and in the five hundred texts proceeding from the presses of the fifteenth century in the nearby Annmary Brown Memorial. In our own Library there is found material of pertinence in the form of a collection of some 300 works from the presses of Aldus Manutius and his descendants. The Aldine group is of particular significance in this connection in that it embodies texts in which the thought and imagination of the ancient world are set forth with mediaeval and Renaissance commentary.

The scientific works of our Aldine collection are supplemented in the Library by numerous early editions from other printing houses of the astronomical and geographical works of Claudius Ptolemy, the works of Strabo, Pomponius Mela, and Solinus, the digest of Ptolemaic and Arabic learning made by Johannes de Sacrobosco, and the gleanings of ancient and modern speculation embodied in the $Y_{\text {mago }}$ Mundi of Pierre d'Ailly. Some of these works, notably the Sphera Mundi of Sacrobosco and the Ymago Mundi, are known to have exercised direct influence upon the geographical concepts of Columbus; all of them are important in the comprehension of his general ideas.

\section{The Period of Discovery and Exploration, 1492-1550}

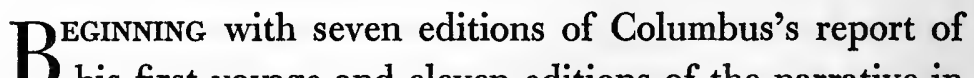
$\mathrm{B}_{\text {his first voyage and eleven editions of the narrative in }}$ which Vespuccius related the events of his third voyage, and carrying on with the works of Peter Martyr, Waldseemüller, Martín Fernández de Enciso, Oviedo y Valdés, with fundamental accounts of the achievements of the Cabots, Magellan, Ponce de León, Cortés, Pizarro, de Soto, and 


\section{Lopiader १९pewen âtung auß Arefillg Zanot.}

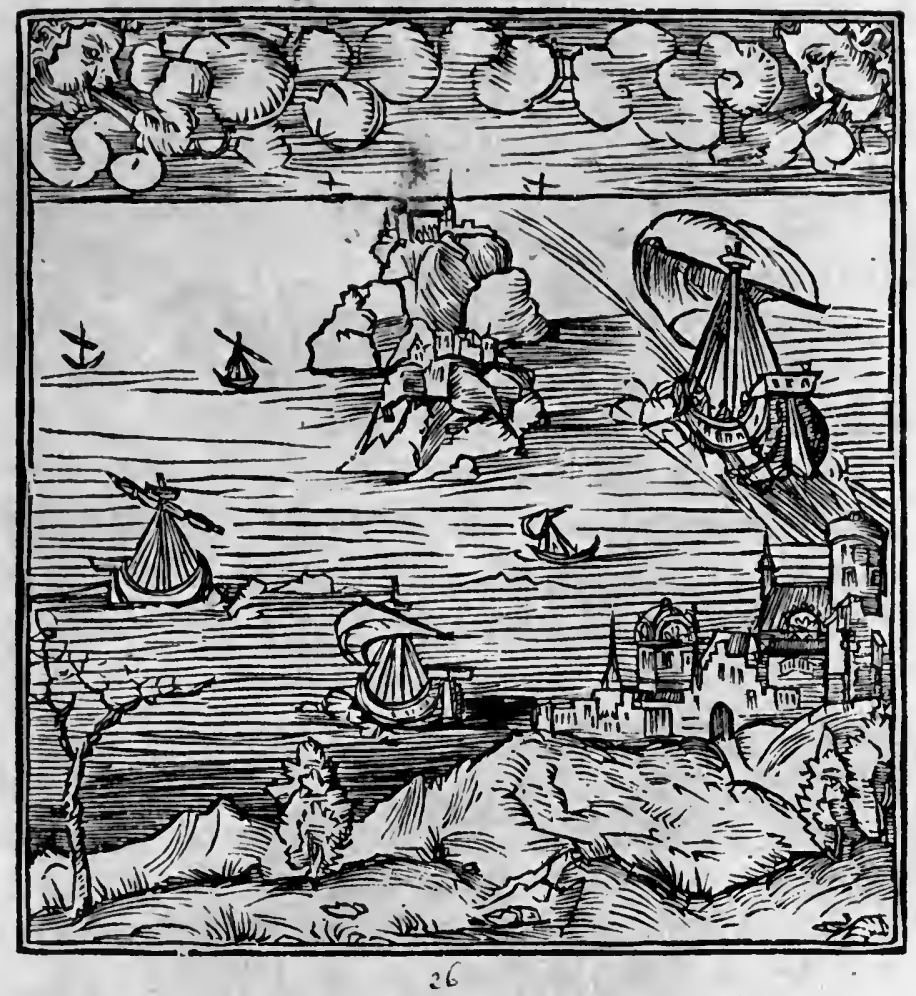

An account of a Portuguese voyage to South America in 1514 believed by many to have influenced greatly current explorations and geographical ideas. 


\section{ZLe bopage et na, \\ uigation/faict par Pes eferpaignof 3 es Gffes deg) ont troutue ausirteopage/ des Rope diceffes/de leur gounernement $(2$ mas niere de bittre/auecplufieurs auftres choles.}

\section{位mpruitegín,}

(1) Di) Pes Deno a Parisen Pa mai/onde

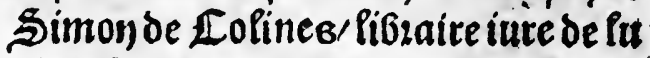
nituerfite de paris/demtoutät en la rue fainct Đeban de Seauluais/a fenfei: gne ou Soleil Dou.

In this work of Paris, 1525, the first circumnavigation of the world was described by Antonio Pigafetta, one of Magellan's companions on the voyage. 
Núñez Cabeza de Vaca, this section of some 300 titles covers in the form of original narratives and general histories the heroic period in the story of the New World. In his Bibliotheca Americana Vetustissima of 1866 and the Additions of 1872, Henry Harrisse organized the bibliography of that period by identifying and recording in their correct places in the scheme 460 titles and editions of titles printed between the years 1492 and 1551, virtually while the events they described were in process of enactment. Naturally this group of raw materials of the American epic occupies a place of special consideration in the esteem of historian and collector. Fifty per cent of the Harrisse entries are in the Library, and with them are found forty-five additional titles and editions which Harrisse would have recorded if they had been known to him.

These productions of actual participants in the discovery, exploration or colonization of America, or of learned reporters contemporary with them, are supplemented by a hardly less valuable group of the second half of the century, that is, the works of historians who went to the official records for their facts and who also collected, compared, and sifted traditions and first-hand narratives. Here is one of the Library's richest fields, containing among other unusual items thirty-seven of the forty-four known editions of the Historia of López de Gómara and twelve of the thirteen recorded editions of the Historia General of Antonio de Herrera. Following these general works are other materials of direct applicability to the history of the period-narrative poems on the conquests, chronicles of missionary activities, collections of laws, histories of the aborigines, works on fauna and flora, drugs and spices, geographical treatises, revisions of older works of geography and science, and 
works on the science of navigation. It is difficult to think of a group of books of greater moment in the history of modern civilization than this in which is embodied the record of the discovery and exploration of America, the conquests of Mexico and Peru, and the establishment of the Spanish colonial empire in the western world. An essential feature of it is the collection of manuscript and printed maps which portray the rapid growth in knowledge of the shape and size of the lands and seas composing the surface of the earth. Though America is the subject of this literature, it is, fundamentally, European literature, arising from the impact made upon European thought and habit by the entry of the new continent into the social, political, economic, and religious life of the elder nations.

\section{The Empires of Spain and Portugal- Mexico, the West Indies, Peru, and Brazil}

statistical analysis of the Library's printed materials
on the Spanish Empire in America shows the following divisions:

Titles in Spanish dealing specifically with Latin America 2,900 Titles in other languages dealing specifically with Latin America

Titles in various languages dealing in part with Latin America

$$
\frac{5,000}{10,000}
$$

This computation, the last element of which is estimated rather than counted, suggests that about one third of the Library's titles printed before 1801 are of direct or complementary interest to the student of Latin-American history. The elements of this large group bear upon so many of the categories later described that we content ourselves for the 
present with the foregoing statement of strength as revealed by statistics. One important feature of this group that must be pointed out here, however, is the large proportion of its titles that proceed from American presses. The typographical origins of the 2,900 books in Spanish relating to Latin America are these:

Printed in Spain

Printed in New Spain

Printed in Peru

Printed elsewhere in Central or South America

It is with special emphasis that we direct the attention of students to the 1,900 books in this section known to have been printed in the Western Hemisphere. First among them must be mentioned the group of 73 titles printed in Mexico City in the period 1544-1600, the incunabula period in the history of the press in America. Representing more than 31 per cent of the 232 titles recorded for that period in Medina's La Imprenta en México, this, we believe, is as large as any group in that category now existing in a public or private library in Europe or America. Of the 'twenty-eight titles listed in Medina's La Imprenta en Lima for the period 1584-1603 (the first twenty years of the press in that city, and, consequently, in South America) the Library owns fifteen, and, in addition, four other imprints of the period not known to the great South American bibliographer. One of these unrecorded titles is the unique copy of the earliest issue of the press in South America, the Pragmatica sobre los diez Dias del Año, of Lima, 1584. This important viceregal order puts into effect in Peru the bull of Gregory XIII whereby was instituted the calendar today in universal employment. The statistics given here are a matter of moment to that increasingly large number of intelligent 
persons who think of the future of this hemisphere in terms of Pan-American solidarity.

The Library's materials for the study of Latin-American history are not confined to those which had their origin in the interests of Spain and her colonies. The story of the Portuguese empire in Brazil is documented in the Library by an important group of materials. Foremost in point of time in this group is a printed copy, of about 1512, of the celebrated Bull of Demarcation of Alexander VI whereby the Portuguese dominion over the newly discovered lands became confined to the northeast shoulder of the southern continent. From the mention of this foundation title in the history of Portuguese America we pass at once to the statement that the standard bibliography of Brazil, the Bibliotheca Brasiliense of J. C. Rodrigues, contains roughly 940 titles of works printed before the year 1800 . Five hundred, or 53 per cent, of these titles underlying the history of Brazil are in the Library's collection. We feel that these works combine with our Spanish-American sources to form a contribution to the history of America almost unrivalled in its completeness.

The activities of Spain and Portugal so pervade every phase of New World history that the literature of their empires forms a considerable element in most of the broad classifications of the Library's materials. For reasons of organization it has been found preferable to discuss this literature from the point of view of subject matter rather than as elements in the broad category implied by the term Latin Americana. Our Latin-American resources are given consideration, therefore, in most of the sections of the book, specifically in: 


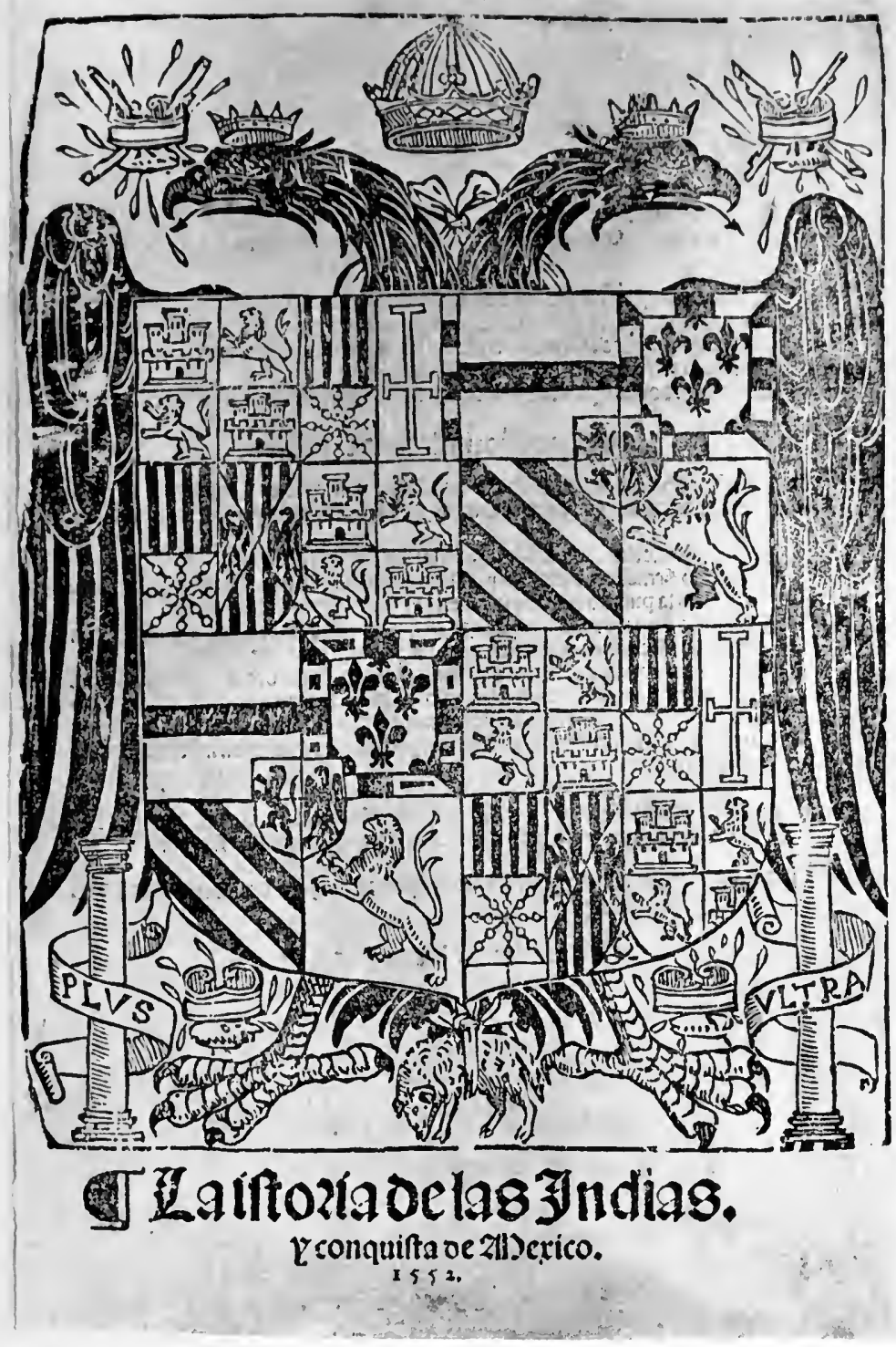

One of the most important records of the Conquest of Mexico is found in La istoria de las Indias of López de Gómara. Here, greatly reduced; is the magnificent heraldic title-page of the first edition of Zaragoza, 1552. 


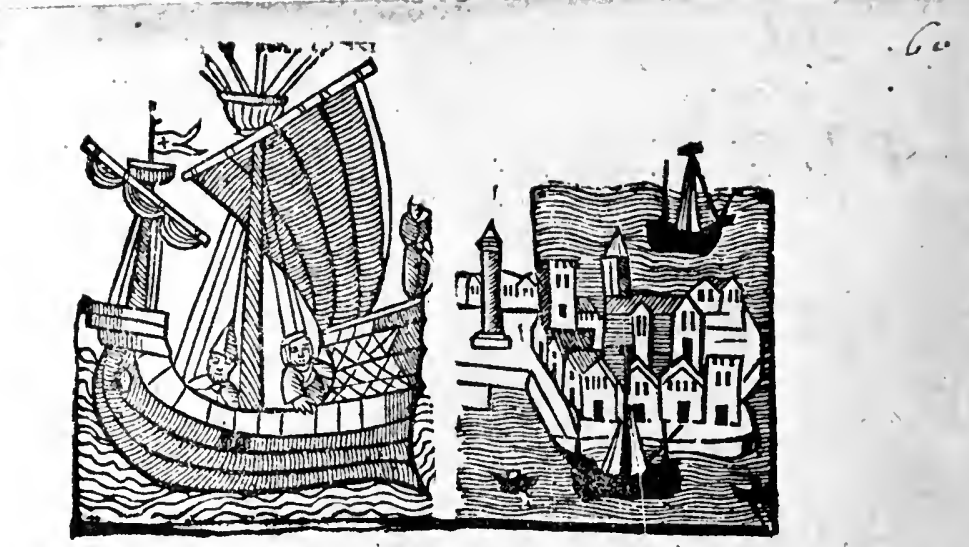

\title{
Sथ OBR A NVEVAMET
}

\author{
TE COM P VESTA, E.N IA \\ qual.fe cuéta, la felice victoria que Dios por. \\ fu infinita bondad y mifericordia, fue fer \\ uido de dar, al Illuttre feñor Pedro \\ Melendez, Almirante y Capitan \\ de la gouernacion de la mar, \\ de las Indias, y Adelātado \\ de la Florida.
}

C O T T A I V A N R I A O. D E N A nacion Frances. Con otros mil Luteranos, a los quales paffo à filo de épada, cō otras cưriofi dades que pone el auctof, de las viuiendas, de los Indios dela Florida, y fus natu. rales fayciones. Cōpuefta en verfo. Caftellano, por Barthòrome de Flores,natural de Malaga y. vezino de Cordoua.

A supposedly unique copy of a Spanish poem of 1569 by Bartholomé de Flores celebrating the destruction of Ribaut's Huguenot colony in Florida in 1565. 
The Period of Discovery and Exploration

Florida and the Southeast of the United States

The Spanish Southwest

New France and Louisiana

The British Colonies of North America and the West

Indies

The Native Languages of America

Church History and Doctrine

The Map Collection

Voyages and Travels

Economics

Science

Law and Government

Bibliography

The Manuscript Collections

Florida and the Southeast of the United States

$7 T^{H E}$ collections pertaining to ancient Florida, that sec1 tion of the United States in which the three rival empires of Spain, France, and England came into conflict, are of particular strength and interest. A few years ago cards representing 450 titles in this category were sent to be filed in the Union Catalogue of Floridiana then being formed at Rollins College. Since that time the Florida Historical Quarterly has published a comprehensive article prepared by us which discusses this group of titles-the source materials, in brief, underlying the history and description of the present states of Florida, Georgia, the Carolinas, Tennessee, Alabama, and Mississippi. Because of the importance of ancient Florida as a mission field, a distinctly large proportion of our materials concerning it are ecclesiastical in character. None the less there are found among them a 
number of political and military narratives and colonization tracts of distinction both as regards importance and rarity. The discovery, exploration, and settlement of the land by the Spanish and their subsequent conflicts with French and English in Louisiana, in the Carolinas, and Georgia; the cessions and retrocessions; and the English occupation and attempts at settlement are all broad subjects for which source materials exist in the collection, illustrated by maps relating to every period and phase of history in the sections particularized.

\section{The Spanish Southwest}

$A_{\text {degree of satisfaction is that which has to do with an- }}^{\text {GROUP of materials in which the Library takes a special }}$ other part of the United States formerly under the dominion of Spain, that is, the area comprising Texas, Arizona, New Mexico, California, and certain parts of the states contiguous to these. This collection contains 198 of the total of 341 printed titles entered in Henry R. Wagner's bibliography, The Spanish Southwest. To these we add several important manuscripts and several printed and manuscript maps of both general and local character. Through the resources of this clearly defined group of materials there may be studied such broad subjects as the explorations of Cortés, Cabeza de Vaca, Espejo, and Coronado; the New Mexican conquests of Juan de Oñate and Diego de Vargas; the reorganization of the frontier provinces as the result of the activities of Pedro de Rivera; the colonization enterprises of Portolá and Anza whereby Monterey and San Francisco were established; the missionary enterprises of Benavides, Pérez, and Junípero Serra; the recording of the Indian languages; the countering of the French encroachment in Louisiana; 
the Russian progress southward from Alaska, and the gradual development of the country by peaceful agriculturists and traders. Material among these sources for the study of specific events and of the history of persons and places adds to their interest. Fifteen of our Spanish Southwest titles are, so far as recorded, known only from the copies in our possession. Except for thirty-five titles of extraordinary importance acquired from the Herschel V. Jones collection in a single transaction of 1939, this group of books, manuscripts, and maps has grown slowly to its present size and value through an interest in the subject deliberately maintained by the successive owners and administrators of the Library for nearly a hundred years.

\section{New France, Louisiana, and the French West Indies}

$T_{\text {HE narrative sources for the history of New France are }}$ 1 antedated by its cartographical records. Upon the world map made by Joannes Ruysch to accompany Ptolemy's Geography of Rome, 1508, the northeastern coast of the North American continent is delineated as part of the coast of Asia and is provided with legends and place names indicative of visits to it by European mariners. This map is found in many libraries. Our own important contribution to the subject of the early cartography of that region is found in the world map of a manuscript atlas made in Naples in 1511 by Vesconte Maggiolo. Upon that map in the appropriate position upon the northeastern coast of Asia are found the place names "Terra de corte reale," "terra de pescaria," "Terra de lavoradore" and "Terra de los Ingres," a nomenclature which records the visits to the American coast of the Cortereal brothers and the Cabots, and constitutes an early recognition of the importance of that coast as 
a fishery. The world map in the Ptolemy of Venice, 1511, shows inscriptions in that general area of a similar tenor, though the outlines of the coast are sketchily portrayed. In 1534 appeared a printed woodcut map of North and South America sometimes called the "Ramusio map," known today only by the copies in our collection and in that of the New York Public Library. Upon that map is an extended coast line in which the northeastern American coast is shown so far as it goes without suggestion of an Asiatic association. Maps of 1546 and 1556 by Giacomo Gastaldi and the map of Nova Franza published by Bolognino Zaltieri in Venice in 1566 join with the Ramusio map and the earlier ones here named to provide the basis of a fascinating record of development in cartographical knowledge, a development of two or more centuries derived from the narratives of exploration by Verrazano, Cartier, Champlain, Jolliet, Marquette, and La Salle. In the later period this cartographical record is enriched by the Jolliet manuscript map of 1674, described in a later section, and a manuscript map of 1678 by the engineer, Hugues Randin. A volume made up by Henry Harrisse, containing a number of contemporary printed maps of New France and several magnificently drawn and colored seventeenth-century maps copied from manuscripts in various French archival repositories, must be mentioned in this brief account of the maps which give distinction to the large body of Canadian source materials in the Library's possession. That collection of printed sources contains the Des Sauvages of Champlain, of 1603; the successive editions of the later works in which that most notable of French explorers and colonizers recorded his ceaseless efforts at empire building; Cartier's narrative in English, the Shorte and briefe narration of 


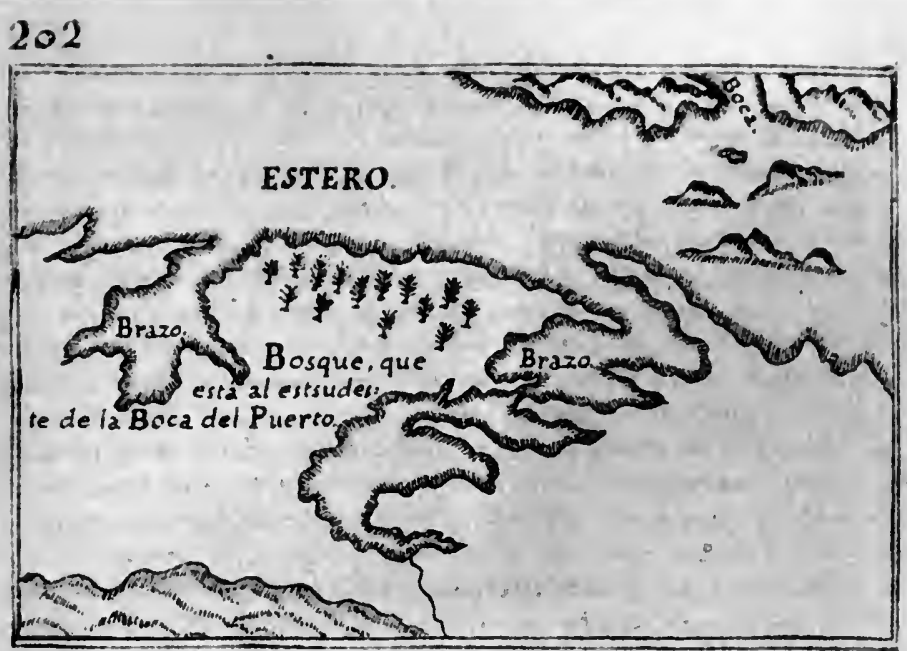

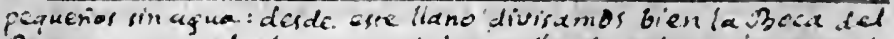
puexto, y quande ia puna del carnil celexado de la paxite in: texiox empaxajo cen la punta eprexicx de la 3oca, mixe a que xumbo coxxian, yvi que coxxian al seste con algunade: chinacional sux, y mé paxecio que el istexo tendxa de anctio delanse de la boca una quatio ieguas, y el camine in a $a$ : paxtado de el come dos lequas. Luego passamor un axxeyo. con algunx xlamedd cexta, y muy poca agua, que paxese rex este d axxoyo que le lland il P. Cxerpide la Bocand. Fxreys atape hay un mont a espersuxa no fxande, y haviendo " wisto xasizo de lor ciexuos gxanda que serialan en di ruclo ia perinia quasicomo la xes, fuaxon les soldades ä bucaxles al mente, y aunque hallaxon, no pudiexson cefex ninguno. Luego segili: mos pox riexxa llana. con alguna lomita, y pox aqui vimos à un indio que estaba en el lians, y luege que nor vio huo ral mis do que se subio pex una loma es xxiendo. y se escendis ár.

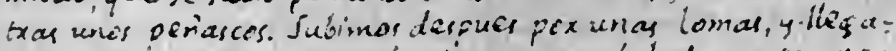
mos a un $a \times x y^{2}=a_{g}$ ixcjunds, y con axboleda y pora afua, y a' su vxilla vimos una xanchexia ierpoblada. Oe aqui segui: mos ya pox llano, ya por lomas, y nos saliexon al camino sie: te Indios, a quiener fio abaloxic al S Comandante, y nessi: y viexsn hasta el axxoyo siguicne. pue no craba muy lejoos, y lo passamor con algun txabajo pox tencx la capa muy pxo:

A map of the present site of Oakland, California, from the journal or Diario of Father Pedro Font, chaplain of the Anza expedition of 1776 which founded the city of San Francisco. 


\section{E T T R E \\ DV PERE \\ C H A R L E S \\ L'ALLEMAN T \\ SVPERIEVR DE LA MIS- \\ fion de Canadas; de la Com- pagnie de I'esvs. \\ Enuoyee au Pere HieroJmel'Allemant \\ Sonfreve, de la me me Compagnie}

Où font contenus les mæư \& façons de viure des Sauuages habitans de ce païs là;

\& comme ils fe comportent auec

les Chreftiens François qui y

demeurent.

Enfemble la defcription des villes de cefte contreen

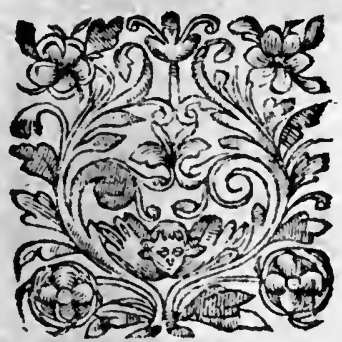

A $P A R I S$,

Par IEAN BOV CHER, luë des Amandiers

à la Verité Royale. I $627 \%$

Written by the leader of the first Jesuit mission to the St. Lawrence area, this Jesuit "relation" of 1627 precedes the great series of similar reports from New France which began in 1632. 
1580; and the general and special works of Marc Lescarbot, issued in the period 1609-1618.

The tremendous part played by the Society of Jesus in $<$ New France is recorded in our almost perfect set of the Jesuit Relations. The whole machinery of life under the French regime-the business of the chartered companies, the church, the army, navy, and governmental agencies, the story of the fisheries and fur trade-is set forth in some 350 édits, arrêts, and ordonnances issued in separate form, and two thousand or more similar instruments found in various eighteenth-century printed repositories of colonial administrative acts. Thus are made available to the student nearly 2,500 French royal acts relating to Canada, Louisiana, and the West Indies. The explorations of the Lakes and the Mississippi; the establishment of Louisiana, the growth of the French policy of encircling the fringe of British colonies on the coast, the struggle with England, the final loss of Can- $\angle$ ada, the making over of a French empire into a British-all the events of this tremendous drama find relation in contemporary works proceeding from both French and English sources. In comparing the works in this section with existing bibliographies of New France we find that we own the same high proportion of materials as is represented by other classes in the Library. The first section of Henry Harrisse's Notes pour servir à l'Histoire, à la Bibliographie et à la Cartographie de la Nouvelle-France, 1545-1700 records 187 titles of the sixteenth and seventeenth centuries. One hundred and seven, or 57 per cent of these, embodying the most important of the titles in their original editions, are in the $\mathrm{Li}$ brary, and to these must be added many other titles and editions of titles not mentioned by Harrisse, a condition that invariably presents itself in checking our catalogue with any 
but the very newest bibliographies. In Canadiana and French Americana in the Library of J. C. McCoy there are recorded for this period and the eighteenth century 325 titles and editions of titles. Seventy-six per cent of these are in the Library. We estimate that of the titles before 1801 in the $\checkmark$ more extensive Gagnon collection, recorded in Gagnon's Essai de Bibliographie Canadienne, 70 per cent of the whole are located on our shelves.

For the study of the French West Indies the Library's resources are equally important. In Dampierre's Essai sur les Sources del'Histoire des Antilles Françaises there are recorded and discussed a selection of 174 titles. One hundred and forty-three of these, or 82 per cent, are in this Library.

A particularly interesting group is that relating to Santo Domingo which includes some 800 titles, especially rich for the period of the Revolution of 1789-1793. Noteworthy among these are several newspapers and many pamphlets and broadsides published in the United States by the Santo Domingan refugees of 1792 .

The percentages given above derive from comparison of our holdings with general bibliographies and catalogues. An examination of our sources for the study of certain topics not yet made the subjects of special bibliographies shows such instances of unusual completeness as these which follow:

The effort of the French in 1612 to colonize the island of Maragnan, off the coast of Brazil, and their subsequent troubles with the Portuguese resulted in the publication of fifteen books and pamphlets. Eight of these, one of them unrecorded elsewhere, are in our collection.

Of the nine news sheets known to have been published in France recounting Braddock's Defeat and the later wilder- 
ness battles of Ticonderoga, Lake George, Forts William Henry and Beauséjour, eight are among our titles relating to the French and Indian War.

Twelve contemporary publications in French and Spanish are recorded as relating to the Huguenot attempt to settle Florida in 1562-1565; eight of these are owned by the Library, and of the eight two seem to be unique.

The Peace of 1763 and the discussions preceding it brought into existence some 130 controversial tracts; 115 of these are found upon our shelves.

\section{The Dutch and Swedes in America}

THE Library's resources on the Dutch settlement of New 1 York include the documents and accounts in Wassenaer's Historisch Verhael, a semi-annual periodical of 16221635 , recording, among other matters, settlements on the Hudson made years before the official establishment of the colony. Among our earliest separate New York documents are the charter (1621) of the Dutch West India Company and the Company's "Freedoms and Exemptions" (1630) for the colony of New Netherland. These are followed by reports from the settlers to the home authorities; poems in praise of the colony; works on the relative importance to Holland of New Netherland and the Dutch settlements in the West Indies and South America; tracts indicating uneasiness at English encroachment in Europe and in America; and, finally, printed and manuscript documents relating to the conquest of the colony by the English. In Stokes's Iconography of Manhattan Island (Vol. VI, 258-264), Victor Hugo Paltsits describes twenty of these Dutch publications upon which the record of the New Netherland settlement is primarily based. Fifteen of those fundamental works, many 
of which survive in two or three copies only, are found in the Library.

In addition to these printed works we own a volume of papers formed by the Lord Chancellor Hyde, Earl of Clarendon, under whose direction was sent out in 1664 a royal commission to stabilize affairs in New England through a procedure which included the taking over of the colonies established by the Dutch in New Netherland and by the Swedes on the Delaware. Copies of the royal instructions, fair copies of letters from Clarendon to the Commissioners, and originals of their letters and reports to him make up a collection of high importance in the history of New England, New Netherland, and New Sweden. In connection with the Swedish colony on the Delaware, the Library is able to show some unusual printed books and maps in addition to the manuscript materials just described. In an exhibition we put on in 1938 at the time of the 300th Anniversary of that colony were shown pamphlets by William Usselinx, promoter of Dutch and Swedish commercial expansion and colonization; the charter of the Swedish South Company under which the settlement was made in 1638; pamphlets on relations with New Netherland and the contiguous English colonies; maps of Maryland, Pennsylvania, New Jersey, and the Delaware area; and works on the history and religious life of New Sweden by members of the colony and later Swedish writers. The eighty titles which made up this exhibition constitute an important bibliography of the Swedes on the Delaware. 


\section{'t $\mathrm{L} \quad \mathrm{O} \quad \mathrm{F}$ \\ Van \\ NUW - NEDERLAND.}

Daar in, kort, engrondig word angewefen d'uytmuntende hoedanigheden, die het heeft in de fuyverheyt des Luchts, vruchtbaatheyt des Aardrijks, voort-teling des Vees, overvloed des Wilds, en Viffchen : met de wel-gelegentheyt tot Schipvaard, en Koophandel.

\section{$D 0,0 R$ \\ JACOB STEEN-DAM \\ (chasc(s)

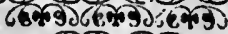 \\ Cros (c)

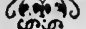 \\ 8 \\ Voor $\frac{x^{\prime} \text { A M S T E R A M }}{\text { J A O B U v van der F Y K : Boekver- }}$}

"The Praise of New Netherland," by Jacob Steendam, a poetical colonization tract known in only two copies, was intended to encourage emigration to the Dutch colony on the North River. 


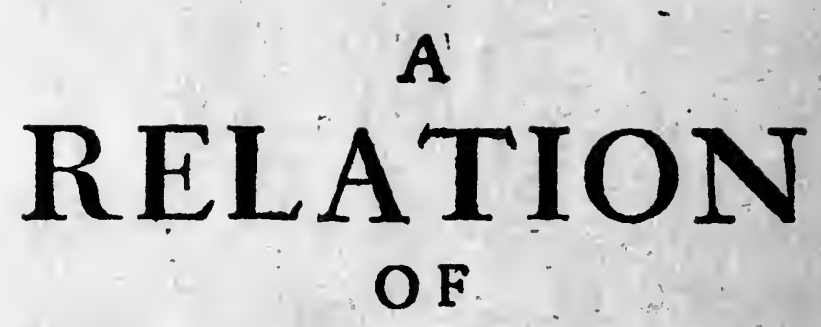

\section{The fucceflefull beginnings of the Lord} BAL TEMORE'S. Plantation in Mary-land.

Being an extract of certaine Letters written from theuce, by fome of the Aduenturers, to their friends in England.

To which is added, The Conditions of plantation propounded by his Lordthip for the fecond voyage intended this prefent yeere, 1634 .

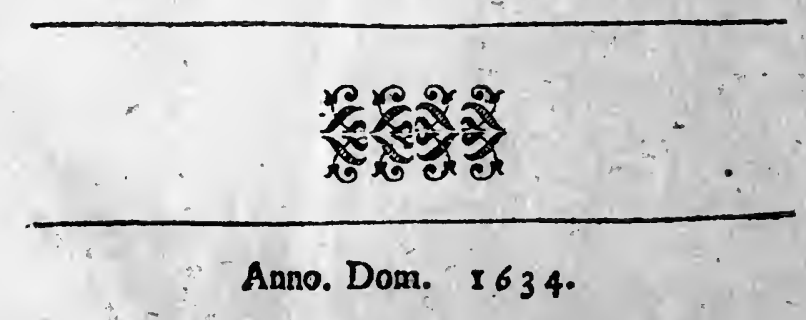

The news of the Maryland settlement was promptly reported and Lord Baltimore's conditions of plantation set forth in the "1634 Relation," known only in this copy and the copy in the British Museum. 


\section{The British Colonies of North America} and the West Indies

$N^{0}$ department of the Library is more satisfactory to the 1 student than the section on British America, which begins with the sixteenth-century translations of Eden, the compilations of Hakluyt, and the original narratives of Frobisher, Gilbert, Drake, and Raleigh, and goes on through the exploration, colonization, and political development of the country to the close of the French and Indian War. Several statistical tests will serve to make clear the commanding position of the Library with its ten thousand titles pertaining to this broad field:

In his Trial Bibliography of Colonial Virginia, part one, published in 1908, William Clayton Torrence credited us with the possession of fifty-six titles and editions of titles published in the hundred-year period 1608-1707, or exactly fifty per cent of the total. At the present time there are in the Library about sixty-four per cent of that same group of titles, representing the printed sources for the first century of Virginia history.

Seventeenth Century Books relating to Maryland, by John W. Garrett, included, at the time of its publication in 1939, 109 titles for the term of years 1612-1700. Of these, the Library owned at that time 85 titles, or 78 per cent of the whole. Before his death in 1942 Mr. Garrett, whose library now belongs to the Johns Hopkins University, had increased his own Maryland collection to an equivalent number of items.

The colonization companies of East New Jersey issued in the years 1676-1683 nine promotion tracts which have come to be called "the Scottish Proprietors' Tracts." Eight 
of these, two of them unique, are in the Library's collection.

Of sixteen Carolina colonization tracts issued between 1664 and 1699, eleven are on our shelves.

Of the fifteen Pennsylvania pieces issued in the fouryear period 1681-1684, eleven are in the Library's collection.

The Catalogue of the Wymberley Jones De Renne Georgia Library (1931) recorded 544 titles and editions of Georgia materials printed before 1801. Two hundred and seventyfive of these entries, plus ninety-six not in the De Renne collection, are in the John Carter Brown Library. This means that there are here about 60 per cent of the Georgia titles known to us for that period.

Statistics as impressive as these might be compiled for all the British colonies of North America, notably for the colonies of New England to which, naturally enough, the attention of the Library was earliest directed. Jamaica and the Sugar Islands of the West Indies are represented by many general works, but particularly by a large group of pamphlets relating to the sugar trade, which scholars have described as an important source of information on the political and economic aspects of that subject. The Bahamas are represented interestingly by five large folio volumes composed chiefly of letters received by George Chalmers while acting as colony agent in England throughout the period 1792-1818. Together with these are found a number of documents of earlier date having specific reference to the Loyalist refugees from East Florida. A group of 150 or more Dutch books and pamphlets of the seventeenth and eighteenth centuries is concerned with the efforts of the States General to establish firmly the trade of the Netherlands in 
the Caribbean area. Many hundreds of pamphlets upon our shelves which were brought into being through the European conflicts of England, France, Holland, and Spain possess direct relationship to the history of the West Indies.

\section{The Revolution}

THE Library's works on the American Revolution begin

1 chronologically where the French and Indian War left off. Earliest among them, it might be said, are thirty-five tracts of Philadelphia, 1764, relating to the Paxton Boys massacre and its political consequences; the last is the welldefined group of 181 sermons of the year 1800 preached in memory of George Washington, between his death in December, 1799, and his birthday anniversary, February 22,1800 , the official day of mourning. In the period between these years, that is, between 1764 and 1800, the nation was born amid the discords and enthusiasms of the Stamp Act Controversy, the Non-Importation proceedings, the Association, the Confederation, the protracted War of the Revolution, the Union under the Constitution, the Indian troubles, the assumption by the new state of a place among the nations, and the rise within it of political parties.

The effectiveness with which this group of materials has been formed is illustrated, let us say, by the fullness of our collection of works on the Stamp Act and other political events and discussions preceding the Revolution. Here is the group of five pieces in the Halifax Gentleman controversy, which came into being when Martin Howard of Newport took the field against Stephen Hopkins of Providence and James Otis of Boston, discussing the Sugar Act of 1764 and other ministerial restrictions upon the colonies. Here is a copy of the Stamp Act, a copy of the rescinding 
Act, and a distinguished lot of pamphlets brought into being through protest against the imposition of the law. Of the seven known editions of the most celebrated of these pamphlets, Daniel Dulany's Considerations on the Propriety of Imposing Taxes in the British Colonies, six are in the Library's collection, including the first edition of Annapolis, 1765. Another group of importance in the history of those ideas about which the Revolution centered comprises 109 issues and editions of twenty-eight works by Thomas Paine. Other instances of the same degree of fullness might be mentioned; it would, indeed, become a simple matter of listing and cataloguing if we were to name many more single works and groups of works in this collection of materials relating to the Revolution. Even so we must not fail to mention specifically our possession of ten editions of that influential and widely reprinted book, John Dickinson's Letters from a Farmer in Pennsylvania; three editions of Thomas Jefferson's Summary View of the Rights of British America, including the rare Williamsburg edition of 1774; and, on the other side of the question, the Massachusettensis of Daniel Leonard, the Bay State loyalist. In this association also there is found in the Library a large collection of writings by English publicists for and against the American cause - on the one hand, Edmund Burke, Charles James Fox, and Richard Price; on the other, the controversial pamphlets of Samuel Johnson, the Rev. John Wesley, and the learned dean of Gloucester, the Rev. Josiah Tucker. There is also to be recorded the presence in the Library of such periodicals and collections of English publication as The Remembrancer and The Parliamentary Register. The interest of continental Europe in the political and constitutional aspects of the Revolution is represented by many 


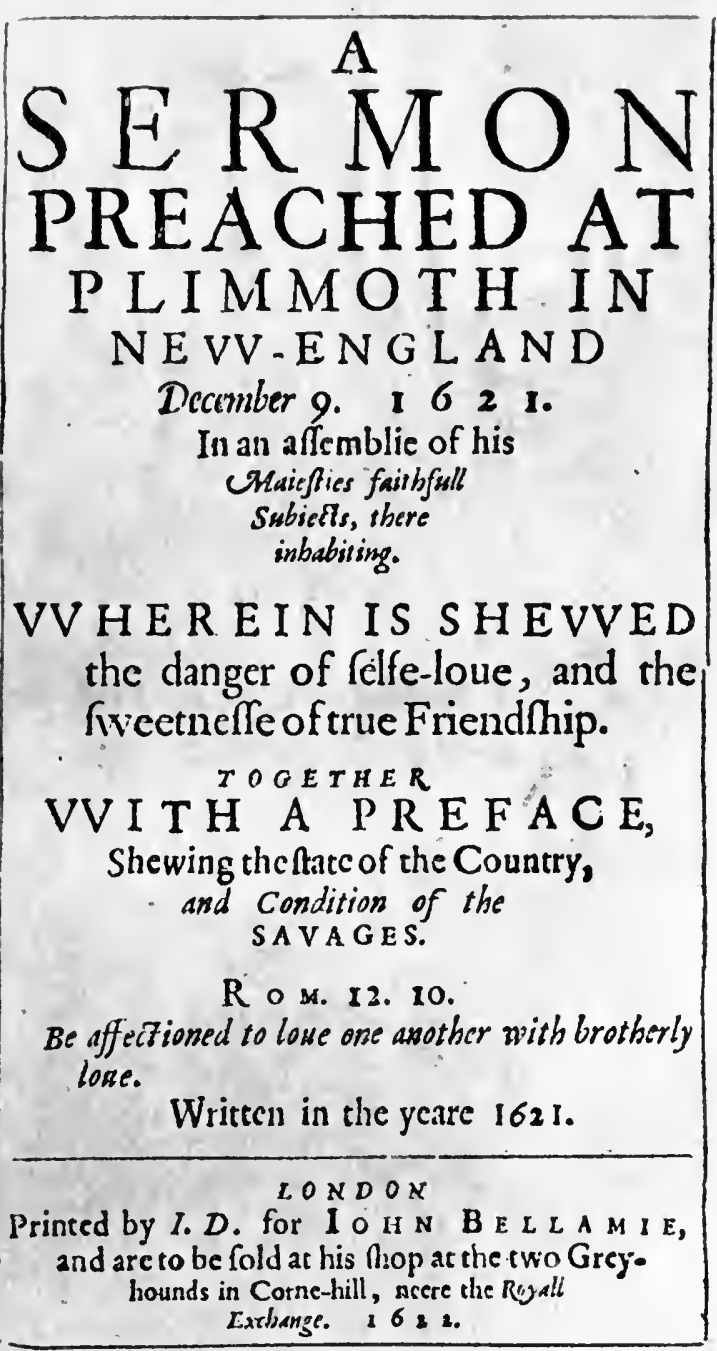

The "Cushman Sermon" was the earliest report in print of the difficult first year of the Plymouth colony. 


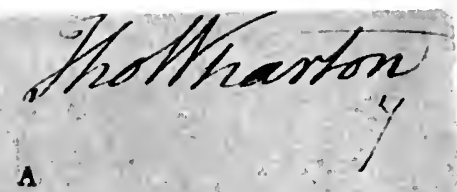

S U M M A R Y V I E W

O F T H E

R I G $\quad H \quad T \quad S$

OF

F R I T I S H A M E I C A.

S E T FOR TH I N SOM E

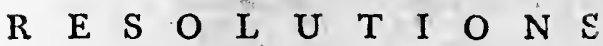
INTENDED FOR THE

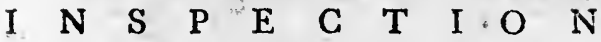

OF THE PRESEN T

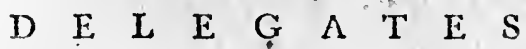

O F T H E

PEOPLE OF VIRGINLA. N O W I N

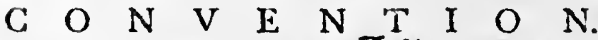

By Thumas Jeffersor

By A N A T I E, AN U M M B ER OF THE HOUSI OF BURGESSES.

W I L L IA M S B UR G :

PRINTED Z ZLEMENTINARIN

Thomas Jefferson's important contribution to the controversy with England, published at Williamsburg in 1774, anticipated the ringing phrases of the Declaration of Independence. 
publications, among them the seventeen volumes of the semi-clandestine periodical, Affaires de l'Angleterre et de l'Amérique, 1776-1779, a publication of Paris bearing an Antwerp imprint.

In the course of a test recently undertaken to determine how extensive were the collections of eighteenth-century Americana in a certain group of libraries, it was found that for the year 1775 there were in the John Carter Brown, exclusive of broadsides, laws, almanacs, newspapers, and doctrinal sermons, a total of 336 titles and editions, printed in both England and the United States, relating to the problems of the Revolution or to the social and political affairs of the individual colonies. A probable total of titles for 1775 in five leading Americana collections of the United States is in round numbers 500. A strikingly interesting feature of our 336 books of the year 1775 is the large proportion among them of locally printed pieces. Two hundred and one, or sixty per cent of the whole number, were printed in cities and towns of the United States.

Among the manuscript materials in the Library are certain groups of high importance in the history of the Revolution, notably the collection of 51 letters from Washington to Joseph Reed, all of which were written in the term of years 1775-1780. Of a different degree and kind of interest are the twenty letters from a chaplain with the Rhode Island troops, written to friends in Providence, a group soon to be published separately by the Rhode Island Society of the Cincinnati. Most important of all, in many senses, are the letters and accounts pertaining to the business between the Brown brothers in Providence and the Secret Committee of the Continental Congress relative to the supplying of clothing, munitions, cannon, and other materials of war by those vig- 
orous and patriotic merchants, an important element in the collection of business papers which we describe at greater length under the heading Economics.

\section{The Constitution}

THE nationalization of the country was completed, in 1 theory, with the adoption of the Constitution in 1787. That easy comment is frequently made without any real comprehension of the intellectual ferment which distinguished the four-year period between the close of the Revolution and the final adjournment of the Constitutional Convention.

To study properly the history of the Constitution of the United States one begins with certain pre-Revolutionary projects for the union of the colonies. In the Library are found several works embodying the suggestions for plans of union put forward by William Penn, Charles Davenant, Daniel Coxe, and the anonymous Virginian who wrote the Essay upon the Government of the English Plantations, published in London in 1701. Not to be overlooked in this study are the collections and separately printed editions of the charters and constitutions of the several colonies as they existed under British rule. As the century grew older, we see the idea of union developing in the writings of Archibald Kennedy, Benjamin Franklin, Thomas Pownall, and Henry McCulloh. The Albany Congress, of 1754, the culmination for the time being of all this earnest thinking, is represented in the Library by a manuscript journal of proceedings. There are here also some unusual materials on the Stamp Act Congress, which was the next tentative effort put forth by the colonies in their search for the strength that comes through union. At least fifteen books, pamphlets and 
manuscripts in the Library relate to these plans of union proposed in the century before the actual Association of 1774.

Following chronologically upon these pieces having to do with colonial plans of union is found another group concerned with the Association and the Continental Congress of 1774 and the Confederation of 1777. These discussions are continued in the years immediately following the war by pamphlets in which serious men seem to be feeling their way towards a firmer union of the newly liberated commonwealths or else fostering the idea of opposition to such a union. Then comes the Constitutional Convention, and, expressing its mood, the Federalist and a series of tracts by Elbridge Gerry, Noah Webster, James Wilson, Richard Henry Lee, Charles Pinckney, Luther Martin, and various anonymous writers. Finally there are editions of the Constitution itself and of debates on the subject of its ratification. Seldom has there been in the annals of the nations a more significant meeting of minds, a loftier passage in the development of the ideas by which men live, than is found in the group of writings roughly outlined in the foregoing sentences. The Library's exhibition of 77 selected titles at the time of the celebration of the sesquicentennial of the Constitution in 1937 represented with singular fullness the thinking of those learned and patriotic men who strove to fashion for the country a comprehensive, just, and flexible instrument of union.

\section{The Western Expansion}

THE Library's materials relating to the development of 1 the West in the two decades following the Revolution can best be described by an analysis of an exhibition com- 
prising seventy selected titles put into our cases at the time of the celebration in 1938 of the sesquicentennial of the Northwest Territory. A group of maps in this exhibition showed the increase in knowledge of the interior from the late seventeenth century to the time of the Northwest Ordinance of 1787. Among these was the Louis Jolliet manuscript map of 1674, celebrated as the earliest portrayal of the results of Marquette's exploration of the upper Mississippi. A companion piece to the Jolliet map in this exhibition was the Hugues Randin manuscript map of North America, 1678. There is little of greater significance in the cartography of the West than these two records of current exploration, one of them, the Jolliet map, being in the nature of a report by one of the leaders of an exploring expedition of major importance. There were shown also Filson's map of Kentucky and Fitch's map of the Northwest, actual implements in the laborious business of settlement. The development of that section reached a new point of departure with the publication in 1787 of the celebrated Northwest Ordinance. Thereafter came Thomas Hutchins's map of the Seven Ranges of Townships and the establishment of a governmental land policy. Though some of the land companies - the Ohio, the Indiana, the Walpole, for exampledate from an earlier period, it is in the years following 1787 that we hear most frequently of such agencies in connection with the activities of speculation and settlement. Notable among them were the second Ohio, the Scioto, the Susquehannah, the North American, and the Illinois \& Wabash companies. The literature, or selections from the literature, of these and lesser companies formed part of our exhibition. Of seven known works by Samuel Wharton on the subject of the Walpole Company, all are on our shelves. 


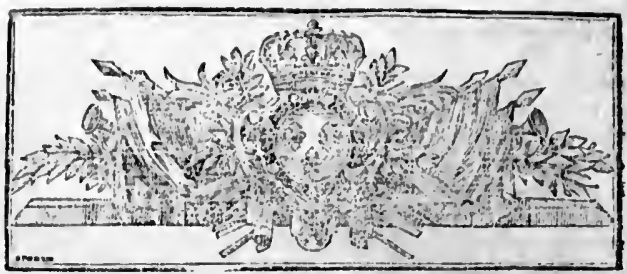

\section{DÉCLARATION}

\section{ADRESSEE

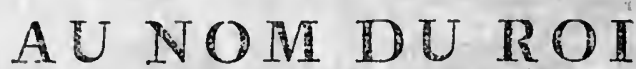

\section{A TOUS LES ANCIENS FRANÇOIS}

DELAMERIQUESEPTENTRIONALE,

T.

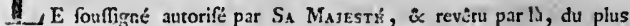
teau des Titres; de celei qui efface tous les autres : chargé au nom du Pere de la Parric \& du Prorciteur bienfaifant de fes fuiers, d'ofirir un appui à cclix qui ćtoient nés pour geủter les douceurs de fon Gouvernement; à rous fus Compatriotes de l'Amérigue Septentrionale.

Vouss ċes rés François, vous n'avez pâ ce Rier de l'ćrc: une Guerre qui ne nous atoit été annoncic que par l'enlévenient de prefque tous ros Mrrelors, \& dont nos ennemis cominutis n'ont dú les princifantx fuctès qu'au courage, au talent, \& au nonbre des Braves Américains qui les combattent aujourd'hui, vous a arraché, cc qui eft Is plus cher it tous les hommes, jufqu'au nom de votre Patrie; vous forcer à porter malgré vous des mains parricides contre elle, feroi lé comble des malheurs, vous en cres ménacés': une nouvelle Guerre doit vous fuire sedouter qu'on ne vous oblige a fubir cettc loi 1. pius révolsanze de l'efclavige : cetro Guerre à commencé comme la précédente, par les dépradations de la partic la plus intúreffante de netre Commerce. I es prifons de P'Amérique contiennient depuis trop longtenis ua grand nombre de François infortuncés; vous critendez leurs géniffiructas. Cetre Gucrre dété diclarée par le nieffage du mois de Mors dernier, par l'A.te le plus authentique de la Souvcräineté

First page of the Admiral d'Estaing's propaganda publication, directed towards securing the adherence of the French of Canada to the American cause in the Revolution. A product of the French Fleet Press, at that time, 1778, operating on board the flagship, the Languedoc, anchored in Boston harbor. 


\section{I E W \\ O F T H E \\ T I T L E \\ T 0 \\ I N D I A N A, \\ A TRACT. OF COUNTRY ON THE

$$
\text { R I V E R O H IO, }
$$ \\ INDIA: conferences at JoH son-HA $L$, in May, 1765 ; the deed of the Six Natrons to the proprietors of INDANA; the minutes of the CONOHESS at FORT STANwIX, in OEgber and Nivember. 1768; the deed of the IN $S$ ANS, fettling the boundary line between the ENGLIsit and INDiANS lands; and the opinion of CoUNSEz on the title of the proprietors of INDIANA.

$$
\text { II I L L I A M S B U R G: }
$$ \\ Printed by J. DixON \& T. NICOLSON. $M, D C C, L \times X I X$.}

The Williamsburg edition of a publication which is at the same time an Indian Treaty and a foundation document in the history of the Western Expansion. "Indiana" was a large tract in the northwestern section of the present state of West Virginia. 
The activities of Manasseh Cutler and Rufus Putnam in the settlement of Marietta, Ohio, the first town established in the new territory, also find strong representation here in print and in manuscript. The early laws of the Northwest Territory are in the Library in volumes printed at Philadelphia in 1792 and 1794, and at Cincinnati in 1796. In addition to these elements of direct interest in the opening of the West, the student of the subject finds important material for an earlier period in our very full set of the Jesuit Relations from New France, in the writings of Hennepin, Lahontan, Tonti, and in such English tracts as John Lederer's Discoveries of 1672 . In a good many other narratives, particularly in the Indian Captivities, Indian Treaties, and accounts of campaigns in the French and Indian Wars, the student finds truly laid the broad base upon which his special studies must be built. The subject ramifies so widely that we are not able to make any sort of statistical estimate of the Library's strength in this field, which has always appealed to the romantic imagination of every American.

\section{The Native Languages of America}

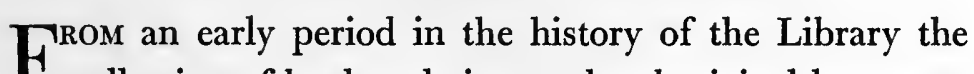
F collecting of books relating to the aboriginal languages of America-grammars, vocabularies, and texts-has been a matter of concern with those who have controlled its policy. The scope of these books, which proceeded primarily from the needs of the missionaries, covers the whole of the Western Hemisphere and comprises a large number of linguistic families. In certain of the languages involved the cultivation of the field has been intensive. When a bibliography by José Toribio Medina on the Indian languages of Peru was being prepared for publication after his death, the 
final work upon it was carried out by its editor in the course of a visit to this Library of several weeks' duration. The reason for that choice of headquarters becomes clear when it is seen that of the forty-nine titles and editions of the period before 1801 recorded in the bibliography, thirty-two, or two-thirds of the whole, are found upon our shelves. A distinctive group of works on the languages of Paraguay, printed in the Jesuit missions of that land by the Indian converts with types of their own manufacture, is among the more unusual elements in our linguistic collection, as also may be considered certain rare works on the languages of interior South America and Brazil. Central America and Yucatan are represented by a number of printed books, but more notably perhaps by the sixteenth-century work known as the Motul-Maya Dictionary, a manuscript of the first esteem among scholars, which, upon demand from various quarters, we have copied by photostat for several libraries and institutions specializing in American linguistic studies. There are here also in manuscript form complete grammars, dictionaries, and texts of the Nahuatl, Zapoteca, Matlaltzinga, Tarascan, Zoque, and Cachiquel tongues of Mexico. The languages of the Hurons of Canada and the MiamiIllinois of the region of the Lakes and the Upper Mississippi are represented in the collection respectively in the form of the Chaumonot and Le Boulanger manuscript dictionaries, documents well known among students of native linguistics. Printed materials of a similar character are to be found in the collection relating to the Timuquan Indians of Florida, various Algonquian families of New England, and the Cahita and Tepeguana of the southwest of the United States. The extent of our collection of printed linguistic works will be comprehended upon an examination of 


\section{ARTEEN LEN}

G VA ZAPOTECA, COM puefto por el muy reuerendo padre Fray luan de Cordoua, de la orden de los Predicas dos esdelta nue, ua Erpaña.

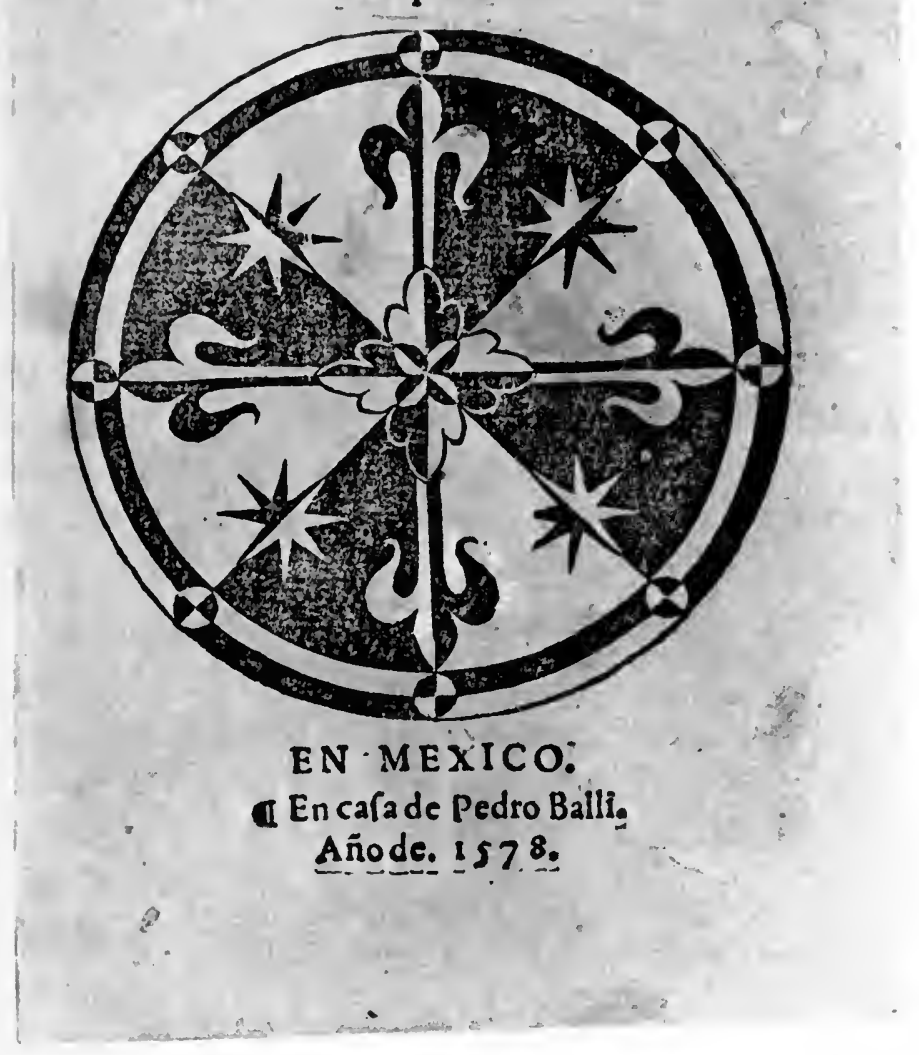

Two special interests of the Library, native linguistics and early Mexican printing, are represented in this book on the language of the Zapoteca Indians, printed in Mexico City in 1578. 


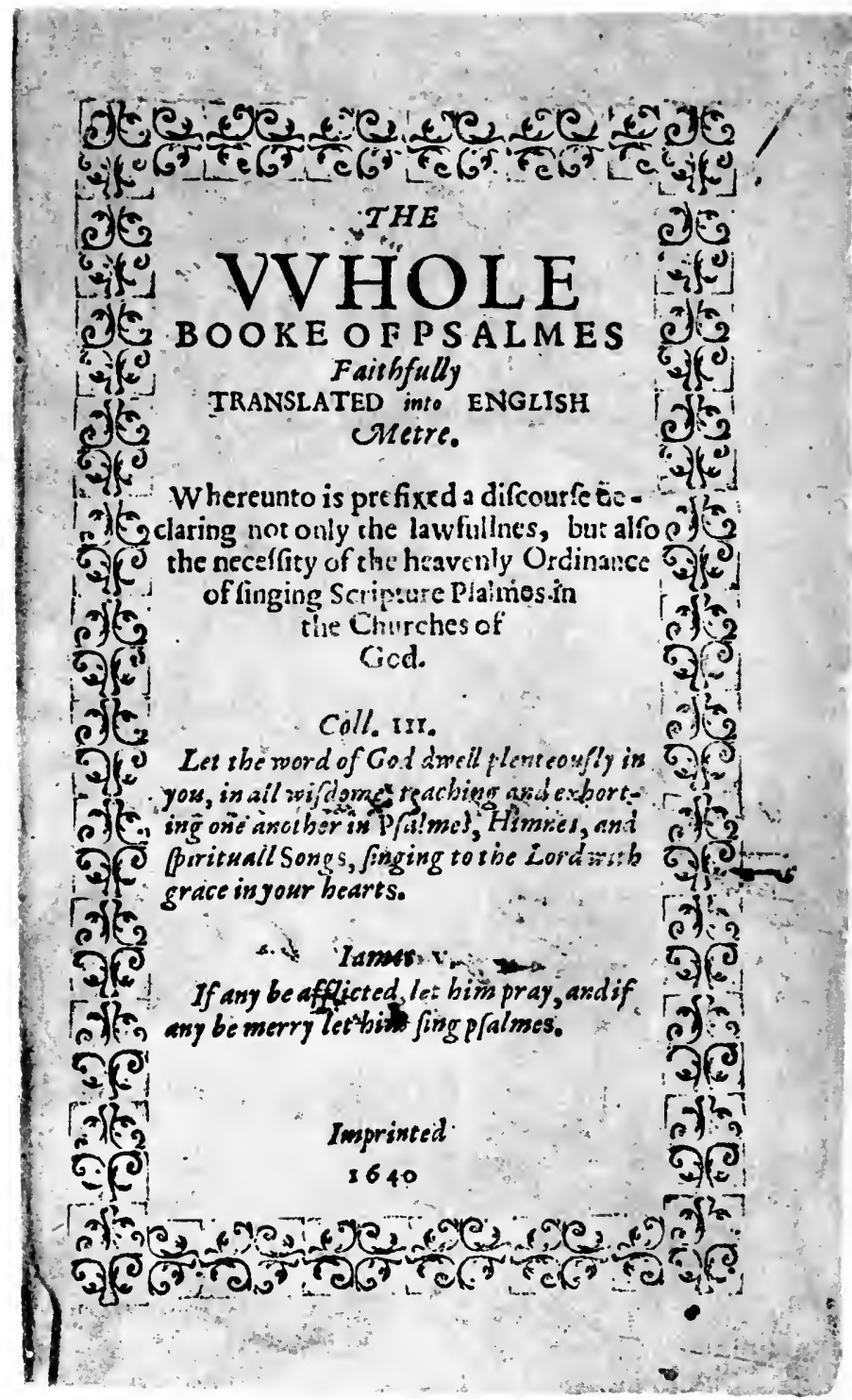

Aside from its religious and literary significance, the Bay Psalm Book of Cambridge, 1640, is of high importance as the first book to be printed in the United States. This perfect copy formerly belonged, as its inscriptions indicate, to the editor of the book, the Reverend Richard Mather. 
Viñaza's Bibliografia Española de Lenguas Indígenas de América. Excluding all manuscripts and all printed works not known in actual copies, there are recorded in that book for the period before 1801 a total of 211 printed editions and issues. One hundred and forty-three of these, or 68 per cent of the whole, are in our collection. That group of printed works is supplemented by fifty linguistic manuscripts and by a large number of vocabularies and texts embodied in works of a general descriptive character.

\section{The Press in English North America}

$T^{H E}$ presence in nearby Worcester in the American 1 Antiquarian Society of great collections of American newspapers and almanacs has made it seem undesirable for this Library to attempt the formation of rival collections in those fields, though inevitably there have come to us in one way or another many items representative of each of them. Outside those categories, however, our policy has been to secure anything printed in the English colonies, interpreting the output of the colonial press, no matter what might be the subject matter of the individual pieces, as an important element in the cultural history of the United States. This very important section begins chronologically with a copy of the first issue known in an actual example of the first press of the colonies, namely, a perfect copy of the celebrated Bay Psalm Book of Cambridge, 1640, bearing the autograph of Richard Mather, its editor. Because of the social significance of the Cambridge press imprints, special efforts have been made to acquire them, with the result that there is in the collection a total of forty-four of its productions, among them the Bay Psalm Book just mentioned, the Narragansett Declaration, the Cambridge Platform, the 
chief of the John Eliot Indian language pieces, the Laws of New Plymouth, and several others of unusual quality. Realizing the importance in American cultural history of the works of the Mathers of New England, we have made a continuous effort to acquire all available publications of that family of preachers and men of letters, so that at the present time, with 275 such titles on its shelves, the Library stands fifth among the seventeen examined by Mr. Thomas J. Holmes in the compilation of his great bibliographies of Increase and Cotton Mather and their sons and brothers, nephews and cousins. Any book of literary intention printed in America has been acquired without question, so that there are here numerous titles of American fiction, drama, essays, and verse. In the field of American poetry the Library's possibility of service to investigators is of unusual consequence because of the presence in the Brown University Library of the Caleb Fiske Harris Collection of American Poetry.

Except for the Bay Psalm Book and the first issues of the press in Georgia and Ohio there is no other work in the collection that can be pointed to as the absolute first of any press of English North America, but there are here so many early imprints from every one of the colonies that the historian of American printing as a whole, or in its many sectional aspects, finds the collection essential to his studies. The effectiveness of the American press in all matters relating to politics and religion is discussed in other sections, but the fact must be mentioned here that of the 2,000 or more sermons in the collection each one has the interest, even when no other is present, of providing a date or a fact in the biography of the preacher and in the history of the church in which it was delivered. 
The foregoing summary description of a large and important group in the Library may be concluded with the statement that a recent calculation shows the presence in the collection of 9,200 titles printed in the English colonies of North America before the year 1801. Evans's American bibliography ceased publication in the middle of the alphabet in the year 1799 with a total of 35,854 titles recorded. Of these 7,382, or nearly 21 per cent, are in the Library. Briefly stated, this is a remarkable percentage of the total recorded production of the American colonial press, placing us in this particular in the class with the American Antiquarian Society, the Library of Congress, the New York Public Library, and the Henry E. Huntington Library of California.

\section{Church History and Doctrine}

$A^{\mathrm{N} \text { important feature of the contents of the Harold Brown }}$ $A_{\text {Room in the Library, housing a collection of books on }}$ the history of the churches in the English colonies, is its abundance of background material. The history of the Friends in Pennsylvania, as represented here, has behind it a large number of tracts of English Quaker interest. The Church of England material rests upon a distinguished group of early Books of Common Prayer and other unusual liturgical pieces of both English and American origin. The chief interest of the collection, however, lies in its universality. Church of England, Congregational Church, Society of Friends, Methodists, Roman Catholic Church, the German sects of Pennsylvania and Georgia, the Baptists in New England and in the South, Presbyterians and New Lightsall these and other organizations are represented in the collection by formularies of faith, controversial works, sermons, hymn books, and materials of other kinds. There are in this 
room and scattered through other classes in the Library some 6,300 titles relating to the religious life and thought of the English colonies.

Moving from the Harold Brown Room to the room devoted to Hispanic America and thence to the section relat-

$>$ ing to French Canada, we find in both places groups notably significant in the history of the Roman Catholic Church. Here are unusual sections devoted to the Jesuits, containing their martyrologies, their Annual Letters, Lettres Edifiantes, and Relations from New France. Side by side with these are the chronicles of the Franciscan and other missionary orders in Mexico and South America, formularies of the church, offices in honor of local saints, biographies, and records of synods. Among our manuscript materials are many documents of an historical or biographical nature, notably the instrument erecting the archbishopric of Mexico, and codices containing little-known works of Las Casas, Alonso de la Veracruz, Joannes Focher, Diego de Basalenque, Maturino Gilberti, and other remembered figures of the Catholic Church in New Spain. The 2,000 printed works and numerous manuscript pieces which make up this classification form one of the strongest units in an American library relating to the history and practice of the Catholic faith in the New World in the colonial period.

\section{The Map Collection}

$\mathrm{T}^{\mathrm{N}}$ an article by Louis C. Karpinski entitled "Cartograph1 ical Collections in America," published in Imago Mundi for 1935, the John Carter Brown collection was commented

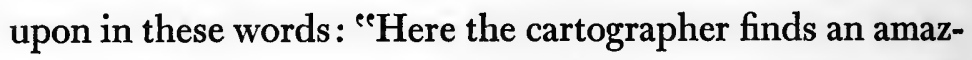
ing number of rarities, manuscript and printed. The annual reports rarely fail to mention the acquisition of more than 


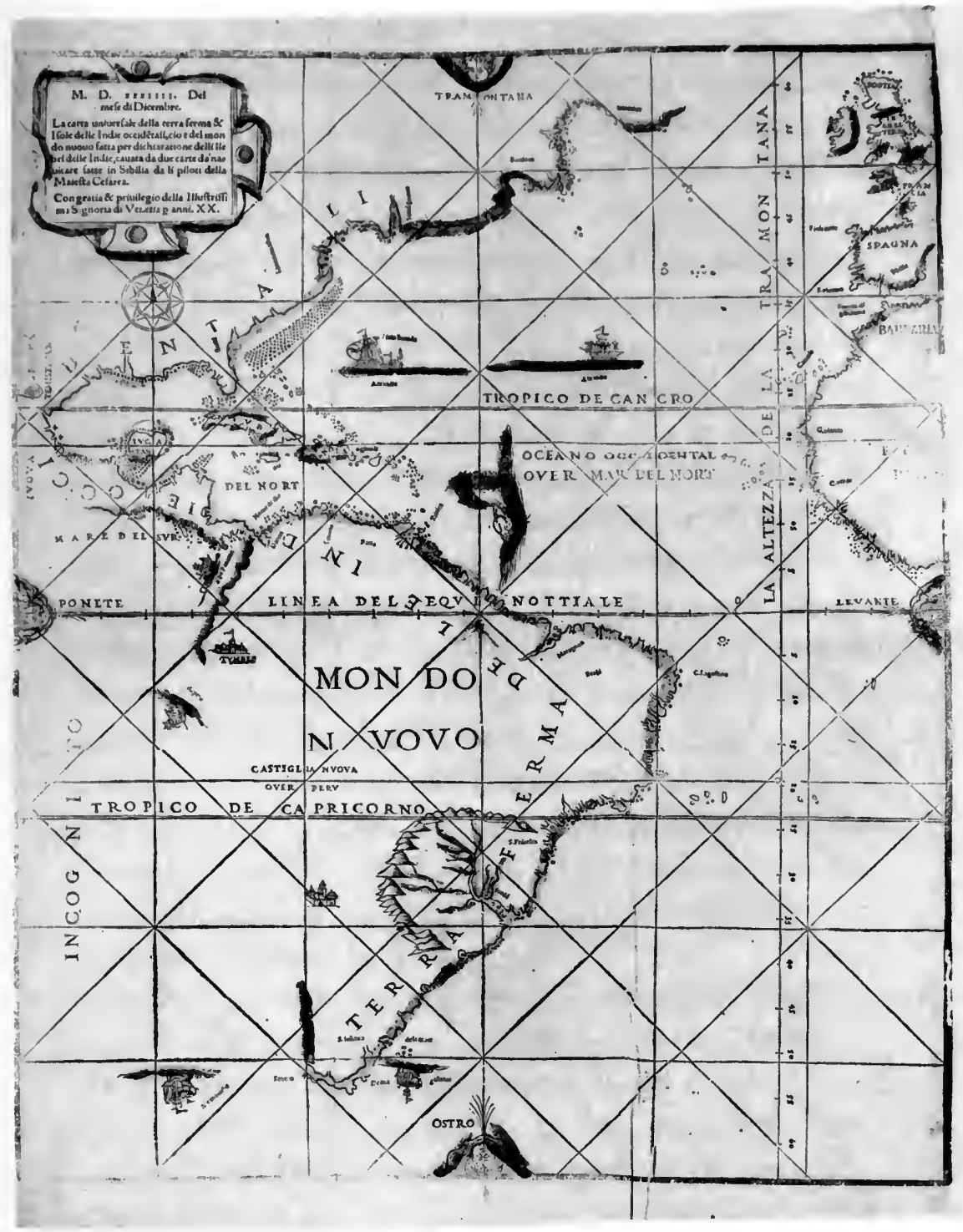

Sometimes called the "Ramusio" map, this woodcut map of America, one of two copies known, shows the remarkable growth in geographical knowledge which occurred in the generation preceding its publication at Venice in 1534. 
one fine cartographical rarity. Both the old catalogue and the scholarly new catalogue are essential reference works in connection with studies in the history of cartography." In view of the special emphasis laid by this writer upon the cartographical rarities in our Library, we must make it clear that the group as a whole is a well-balanced one, composed not alone of rarities but of many hundreds of maps carefully selected to form a working collection in the history of American cartography. The rarities in this collection are simply elements in its scheme, though looked at from another point of view they are its particular glory. The cartographical collection begins with a copy of the earliest atlas ever to be published in print, that is, the edition of Ptolemy's Geography, printed at Bologna in 1477 but incorrectly dated 1462. Upon the foundation thus provided is built a collection of the printed editions of the Geography of the first rank. Of the forty-six known editions of the book printed before 1801 the Library owns forty-four. Next in importance in the collection of geographical atlases is a group of editions of the Theatrum Orbis Terrarum of Abraham Ortelius, beginning with the first of Antwerp, 1570 , in two issues showing important variations. The atlas collection includes also the noble volumes of Mercator, Blaeu, Jansson, Coronelli, Dudley, Speed, and various productions of the later century by Delisle, Sanson, Jefferys, and many others. It contains, furthermore, the portolan atlases of Vesconte Maggiolo (1511) and Battista Agnese (circa 1545), and a group of printed sailing directions which includes a splendid copy of Luke Wagenar, The Mariners Mirrour, of London, 1588, six editions of The English Pilot (West Indies), and several others of Dutch or French origin. Though the map collection as a whole is American in its 
interests, the presence in it of so many of the universal atlases makes it a source of value for the study of broader geographical concepts. The whole modern development of geographical knowledge is traced in the series of atlases in the Library that begins with the Ptolemy of 1477 and runs through three centuries to the Atlantic Neptune of 1780 , or, let us say, to the charts of the Vancouver voyage of 17911795. Particularly is this the case with the geography of America, the two huge continents which presented scholars with a cartographical problem unprecedented in size and difficulty.

In 1943 when the war in the Pacific and Indian Oceans had become a matter of the utmost concern to all the nations of the world, the Library's cartographical resources for the study of the great Pacific area proved to be important and of exceptional interest. An exhibition of some forty maps showed graphically the historical development of knowledge of the seas, islands, and continental lands of the Pacific and Indian Oceans. A brief descriptive account of these maps grew into a monograph, published in 1944 by the Bibliographical Society of America. In this study the cartographical discussion was illustrated by reference to the voyages of discovery and exploration through which the geographical knowledge had been attained by the map makers. The Library was able to show an astonishingly large percentage of the maps essential to an understanding of the subject and of the original narratives of voyages upon which the maps were based. A few years ago the far Pacific was not an American subject; today and hereafter it is a factor in our national life.

The loose maps of the collection are almost entirely American in locale; even the world maps have been chosen 
for the light they throw upon the development of knowledge of the New World. In a recent exhibition of world maps put on by the Library, twenty-four items, printed and manuscript, were shown, ranging in date from 1410 to 1774 . Ten of these maps were either unique manuscript maps, printed maps unique among American libraries, or maps like the so-called Ramusio map of 1534 and the Waldseemüller-Stobnicza of 1512 existing in, at most, two to four known copies. Our printed maps of North and South America begin, in importance certainly, with the Ramusio map of 1534; for the years thereafter we are able to show a long succession of general American maps, each one of which adds its bit to existing knowledge of the continents.

Atlases made up for private owners in the late eighteenth century or early nineteenth contain many general and sectional maps of the seventeenth and eighteenth centuries. The cartography of English America down to 1685 is developed in an atlas made up at about that date for or by William Blathwayt, secretary of the Lords of Trade. Not only does this "Blathwayt Atlas" contain a number of printed maps of rarity and consequence and several unique manuscript maps of different English colonies of North America, but there are in it a number of maps of the English colonies in the West Indies and South America and the English stations and factories in Africa and India. The volume is, briefly described, a cartographical representation of the British Empire as it existed in the period 16801690.

Sectional maps of English America are found in thenotable productions of John Smith, Augustine Herrman, Cyprian Southack, John Filson, Bernard Romans, Lewis Evans, Matthew Clark, and John Norman, and in the commoner 
but hardly less important productions of Mitchell, Fry and Jefferson, Hutchins, Sauthier, Jefferys, and other English and American cartographers. A particular feature of the collection is its high proportion of the maps of British North America, or of individual colonies, known to have been printed contemporaneously in this country. It is beyond our power at this time to estimate the number of maps of America used as illustrative matter in books of history, travel, and description. Some of the rarest or most important of all-the Waldseemüller-Stobnicza, the so-called Ramusio, and certain of the Gastaldi maps-are of this sort. The maps in the John Carter Brown collection-in atlases, in books of sailing directions, in portfolios of loose maps, and bound in books of history and description-present to the special student of cartography and to the student of American and general history an opportunity for study of the most exceptional nature.

\section{Voyages and Travels}

$\mathbf{T}^{\mathrm{T}}$ is told of a celebrated French student and compiler of 1 voyages of the seventeenth century that on his deathbed he inquired of a visitor, "What news do you bring of the Grand Mogul?" That eagerness for knowledge of far lands and their peoples, inherent in the intellectual make-up of mankind, was intensified by the great achievements of Columbus, Bartholomeu Dias, and Vasco da Gama in the last two decades of the fifteenth century. The first collection of American voyages put into print was the Libretto de tutta la Nauigatione de Re de Spagna of Venice, 1504. This piracy of Peter Martyr's first decade comprised the first three voyages of Columbus, and was the first account in 
print of the second and third voyages. The Paesi Novamente retrovati, of Vicenza, 1507, reprinted this collection and added to it the Portuguese voyages along the African Coast and around the Cape to India. Thereafter the booksellers found it profitable to feed the fires of curiosity by the production of a constantly expanding literature of travel. The Columbus letter in seven separately printed editions, the Vespuccius third voyage in eleven editions, and the two general works just named, the Libretto and the Paesi, are $\angle$ the fundamental pieces in the Library's collection of 1,000 or more accounts of American voyages of three centuries which have preserved for this and later ages a picture of the physical world growing through man's restless activity almost too fast for his comprehension.

In the possession of narratives of the single voyage, from Columbus through Magellan, Drake, Raleigh, Hudson, the Dutch explorers, Bering, Cook, and Vancouver, the collection is of fine quality whether it deals with familiar or littleknown names, with the continent of North or South America, with explorers of Spanish, English, French, Dutch, or German origin. Reprints of individual narratives and first printings of manuscript accounts and journals form the matter of the great collections of voyages which by their content and interest have taken high rank in world literature. Ramusio, Galvano, Münster, Hakluyt, Purchas, Lin- < schoten, De Bry, Barros, Saeghman, Thévenot, Van der Aa, Fernández de Navarrete, and a number of other collections of world voyages and voyages in particular areas-touching upon Asia, Africa, and the North as well as America-are in the Library in their chief early editions and issues, supplemented by the modern publications of the Hakluyt So- $\angle$ 
ciety and the Linschoten Vereiniging. An important element in this section is formed by the narratives of Arctic exploration next to be discussed.

\section{The Far North}

7 HE earliest exploration of the Far North was carried out 1 in the fourth century B.C. by an organized expedition under Pytheas of Marseilles. Here was no accidental discovery by a storm-driven mariner, but an exploration deliberately undertaken by a Greek merchant and pilot of southern France to locate those northern markets and mines previously monopolized by the Phoenicians. A skilled as-

$>$ tronomer and a bold sailor, Pytheas is a worthy prototype of those adventurers who for some twenty-two centuries have been following him into northern waters. In the course of his expedition he circumnavigated Britain, measured its coasts, and explored its interior, but without doubt the most exciting news he brought back to southern Europe was the account he acquired at second hand of an inhabited island even farther north than Britain, that is to say of Thule, the Ultima Thule, which lay beyond an icy sea six days northward from the tip of Scotland. The narrative of Pytheas has disappeared, but parts of it have been preserved in passages quoted by scientists of immediately succeeding centuries. It is in the works of Polybius, Strabo, and the younger Pliny, quoting Pytheas with the idea of discrediting his facts and theories, that one must seek the fragmentary story of the first northern exploration. Claudius Ptolemy of about 150 A.D. was more hospitable than these men to new ideas. Because of his willingness to believe, we find in both his text and his maps the "Insula Thyle" of Pytheas accepted and set down as the farthest north known to the men of his time. 
Because of its background material, its ancient scientific texts, the Library's record of northern exploration goes back in both books and maps to this beginning of a great adventure which still challenges the human spirit, back to a copy of the magnificent Strabo of Venice, 1472, to the Aldine editions of Polybius, 1521, and Pliny the Younger, 1535, and to the notable first Ptolemy with maps, published at Bologna in 1477 with the incorrect date 1462.

After the exploit of Pytheas there was little increase in knowledge of the North until the far-ranging Norsemen forced themselves and the lands they inhabited upon the attention of Europe. A further dissipation of the Arctic mists occurred when in the ninth and tenth centuries these Norsemen made their way to Iceland, Greenland, and the northeast coast of America. That expansion of knowledge finds record in the Library's collections in the Sagan Landnama, the Christendoms Saga, and Ari Thorgilsson's Schedae Ara Prestz Froda Um Island, compilations of the twelfth and thirteenth centuries found here in editions printed by Hendrik Kruse at Skálholt in Iceland in 1688, their earliest appearance in print. Records of the disputed voyages of the brothers Zeno in the fourteenth century, and the authenticated northern expeditions of the Cabots and the Cortereal brothers are also to be found in the Library in special works and collections well known to the historian. The great work of Olaus Magnus, Historia de gentibus septentrionalibus, is on our shelves in four editions of the midsixteenth century and in others of the seventeenth.

In the nineteenth century the North Pole became a goal in itself and the effort to attain that goal the most perilous and the most expensive of outdoor sports. But for centuries before that time a lively Arctic exploration had been in prog- 
ress. The explorers of many hundreds of years, with practical commercial needs in view, had persistently been seeking passage to China and the Indies by way of the waters north of Asia and America. The searches of those adventurers for the Northeast and Northwest Passages remained for centuries the most important factor in the exploration of the

$>$ Far North. Its record is starred with the names of Frobisher, Barents, John Davis, Baffin, Hudson, and a large number of others, the narratives of whose voyages have been sedulously brought together by the successive owners of the Library in separate publications and in the collections of Hakluyt, Purchas, and Saeghman, in the Recueil de Voyages au Nord, and in other compilations dating from the sixteenth to the nineteenth century.

In the eighteenth century a revival of interest in the North occurred with the renewal by the Danes of missionary activity in Greenland. Sometime in the fifteenth century the polar twilight closed around the Norse settlements in Greenland and hid them thereafter from European knowledge and contact. When the Egedes went out in the eighteenth century to search for the ancient settlements they found little to indicate that these had once existed. Missions were begun among the Eskimos by Hans Egede and a colony established at Godthaab from which derives the Greenland of today. Of the twenty-six works and editions of works known to have been produced in connection with this movement by Hans and Paul Egede, nineteen are in our collection. Another revival of interest in northern exploration occurred when in this same century Arthur Dobbs, civil servant and publicist, stimulated a search for the Northwest Passage by way of Hudson's Bay. In our section on the Far North are some twenty-five books and pamphlets pertaining 
to the efforts of the Dobbs expeditions to find a northwest passage and to the Dobbs-Middleton controversy which grew out of those efforts.

An interesting part of this literature of the North has to do with the activities of the Russians in the Siberian Arctic, with their explorations of the Northern Pacific under Vitus Bering, the exploration of Bering Strait, Bering's discovery of Alaska, and the Russian occupation of that northern tip of the continent-all events with important implications documented by fundamental narratives, maps, and controversial writings found in our collections.

Because of its date limitations the Library is not concerned with the nineteenth-century epic of polar exploration, but the vast literature which grew out of that search and the literature which is still to be created about the North-now more than ever an element in the life and calculations of the world-is based upon the works of the earlier centuries here briefly described as forming an interesting category in our section devoted to Voyages and Travels.

\section{Economics}

A Distinguished American historian once remarked that A the John Carter Brown Library was of little use to him because it had no division devoted to materials for the study of economic history. It was a pleasure to instruct him. $\mathrm{He}$ was assured at once that there were at least five thousand printed pieces in the Library which had bearing upon the economic history of Europe and America. We made it clear that there were good reasons for the absence from our classification scheme of any section headed Economics. Economics, in our conception, is not a thing in itself, but a thread that runs through all historical action and development. It 
is only by making a cross section of the history of a place or period that its economic aspects take their proper place in the structure, and it is only by a similar study of our various collections that we arrive at some notion of the extraordinary strength of the Library in economic history.

To begin with, there are in the early books of the Discovery and Exploration Period and in innumerable later works the evidences of that extensive exportation of silver to Spain which ultimately altered the basis of European economy. Coming down the centuries we find in the Spanish-American materials a large number of books and pamphlets having to do not only with silver as an element in economic life, but with the mining of silver, with the status of the native workers in the mines, and with the efforts of the government to put a stop to the illegal trade in silver conducted with foreign nations. In a later section dealing with the legal collections in the Library will be mentioned the large number of Spanish-American ordinances that attempted to regulate the place of the aborigines in industry as well as in the social scheme of the community.

One bookcase in the Library containing some 450 titles on Jamaica and the West Indies, elsewhere briefly referred to, is almost entirely economic in its bearing, relating either to the sugar trade or to the conflict for commercial supremacy in that area among the Spanish, English, and Dutch. We have no exact parallel in the Library's history to the story of the poor relation who came to dinner and stayed nine years, but we remember with a great deal of interest the English scholar who stopped off between trains to see if we had any material on the West Indian sugar trade and stayed with us for six weeks. When that scholar left, he informed us that the material in the Library on the sugar 
trade was more abundant and more comprehensive in its character than that of any collection known to him in England or America. A great deal of this material is controversial in character, a fact which is appreciated by the trained scholar who wants to know both sides of the subject as contemporaneously understood. Fortunately, not all are so naïve as the student who told us that these tracts were of no use to him because each one contradicted the other.

We have mentioned before in other connections the group of titles in the Library relating to the Peace of 1763 . In the several controversies which grew up before and after that peace, economic considerations were of the highest importance, and that fact is obvious to the historian who makes use of this special group. The collections already described relating to the West, the progress of the land-developing companies, and the accounts of their disasters and successes are fundamental documents in the economic history of the United States. A large group of works in various divisions of the Library relating to the growing and marketing of tobacco and its place in the political and economic scheme in both Hispanic and English America provides particularly interesting sources for the historian. Other separate groups of value are those which relate to the disastrous activities of the Mississippi Bubble of the great John Law, and to its English counterpart, the South Sea Company. Underlying the sources on the John Law activities are many French royal administrative documents concerned with the business of the Compagnie d'Occident and the Compagnie des Indes. In the affairs of English America we find, in addition to the material essential to an understanding of the tobacco colonies, Virginia and Maryland, representative groups arising from the problems of other sec- 
tions, such a group, for example, as that which relates to the currency questions of seventeenth- and eighteenthcentury New England.

Perhaps enough has been said to indicate that the Library has not devoted itself purely to the political, military, and romantic aspects of American history. Its ideal of providing the answer to any question that could be asked on the subject of the history of America has included always the economic tract as one of its chief instruments.

So far in this discussion of economic materials we have been thinking only of printed books and tracts. Unquestionably the most distinctive contribution of the Library to the study of business and commercial history in the United States is found in the collection which we know as the Brown Papers, an accumulation of some 350,000 letters, invoices, prices current, legal documents, ledgers, daybooks, ships' papers, logbooks, and miscellaneous pieces proceeding from the business activities of the successive generations of the Brown family from 1750 to 1850 , including the papers of Nicholas Brown \& Company, Brown \& Benson, Brown \& Ives, and such related concerns as the Hope Furnace and the Spermacetti Candle Factory, and such activities as western land development and the manufacture of cotton. It is believed that no collection in America offers so many facets of interest to the economic historian or so well displays the history of American business in its successive stages from maritime occupations to land development, and thence to manufacturing. The complete calendaring and indexing of this large collection of important papers is now in progress.

Another collection of papers in the Library relates to the woolen mills established in the South County of Rhode 
Island by Rowland Hazard and carried on by successive generations of his family. The "Peace Dale Papers," as this group of several thousand letters, invoices, and account books is called, are sources in the early history of textile manufacturing in America, particularly as regards the making of woolen cloth. The Library has received also, as a gift from the Honorable Theodore Francis Green, United States Senator from Rhode Island, and Mrs. Erik H. Green, letters, accounts, logbooks, and miscellaneous papers covering the activities in the period 1771-1864 of the Providence mercantile houses of Welcome Arnold and Samuel G. Arnold and their several partnerships and associated companies.

\section{Science}

$T_{\text {Hоugr we have in the Library's classification scheme }}$ 1 a section devoted specifically to science, our sources for its history in America are by no means confined within rigid and categorical limitations. Science travels the byways as well as the highways of history, so that more than once earlier in this progress through the collections of the $\mathrm{Li}$ brary we have encountered in unexpected places fundamental works and groups of works upon which rest our materials for the study of that subject in its many divisions. In our discussion of the Pre-Discovery Period we mentioned the noble editions of the works of Aristotle, Plato, Lucretius, and other philosophical writers of the ancient world as forming an important element in the background of the age of Columbus. In that same section and in the later account of our maps we mentioned the Library's collection of the geographical works of Claudius Ptolemy and Abraham Ortelius, while in those and other sections we called attention to our important collections of the works of 
the cosmographers-of Waldseemüller, Sacrobosco, Peter Apian, and Gemma Frisius. If we had described fully our collection of books printed in Mexico in the sixteenth century we should inevitably have mentioned the works it contains on navigation, shipbuilding, military art, and medicine, especially commenting upon the philosophical works of Alonso de la Veracruz, whose Phisica Speculatio of Mexico, 1557 , has the distinction of being the earliest work on physical science to be composed and printed in the New World.

The necessity of safe travel to the newly discovered Indies, East and West, was the impelling force behind the great advance in the science of navigation which took place in the century following the period of the Discoveries. Because of this relationship between America and the science of the sea, works on navigation are properly included in a collection of Americana. The use of instruments of observation and tables of declination, the development of methods of determining latitude and longitude, statements of the fundamental principles of astronomy-all found their way into the series of practical handbooks which go under the name of navigation manuals. The Library's collection of these begins with many editions of the astronomical syllabus of Johannes de Sacrobosco; it contains copies of John Werner's commentary on Ptolemy, Enciso's Suma de geographia, the manuals of Francisco Faleiro, Pedro Nunes, Pedro de Medina, Martín Cortés, Samuel de Champlain, John Davis, and Nathaniel Bowditch, whose $\mathcal{N}$ erw American practical Navigator of Newburyport, 1802, is still, after many revisions and expansions, the chief American contribution to navigation science. As a complement to the maps made by the early explorers were compiled those written descriptions of coast lines, harbors, and courses 

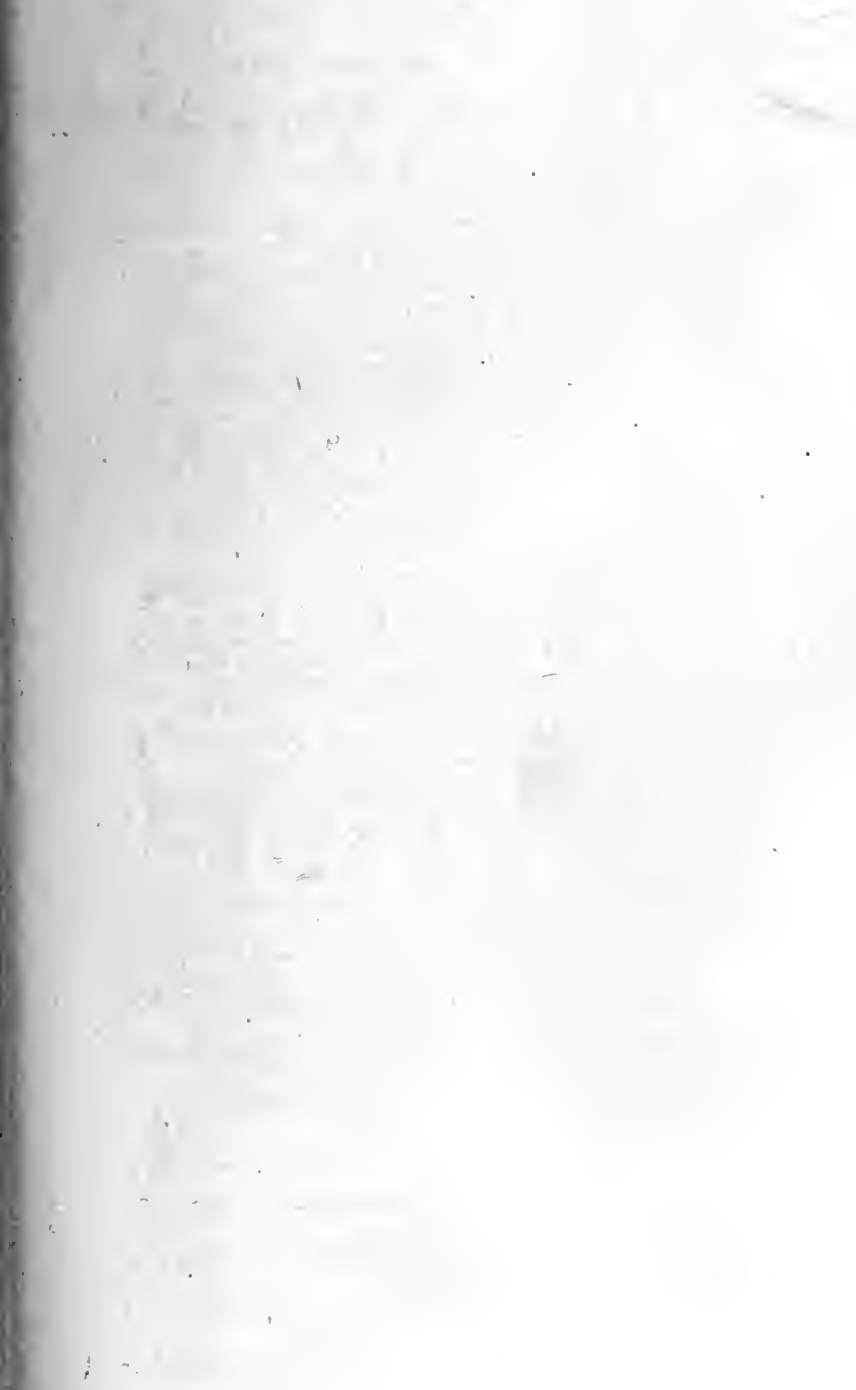

\% 


\section{Several REASONS}

\section{Proving that Inoculating or Tranfplanting the Small $\mathcal{P} 0 x$, is a Lawful Practice, and that it has been Bleffed by GOD for the Saving of many a Life.}

\section{By Increafe Matber, D. D.}

Exod. XX. 13. Tlou Jhals not kill.

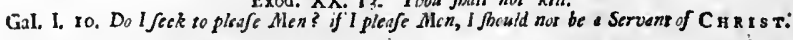

It has been Queftioned, Whether lnoculating the in Nert-England. My Sentiments, and my Son's Small Iox be a l.awful Practice. I incline to alfo, about this Marrer are well known. Alfo we the Affraiative, for thele Reafons. hear that the Revererd and Learnod Mr. Solcmon Sroddert of Norsbampron concurs with us, fo doth

Ecaufe I have read, that in Smyrna, ConAtuningle,and other Places, Thoufands of Lives have been faved hy inoculation, a) noc one of Thoufands has mifearried by it. This is related by IVife \& Learued Men who Perions of a Prophane Life and Conrerfa. rative. Which alio has been publifhed by the and I have been anfwered, shat they know but of Roysl Srciery; therefore a greac Regard is due to it. very few fuch. This is to me a weighty ConfideII. WE beat rhat feveral $P^{\prime}$ j, freians, have Recom- ratior. But on the other hand, tho' there are fome mended the Praclice hereof to His liejefty, as a Worchy Perfons, that are not clear about it ; neverMeans to preferve the Lives of his Subjects, and thelefs, it cannot be denied, but that the known that His Wifc and Excellent Hizjeffy KingubURGE, Child teil of the Wicked one, are generally fieree in

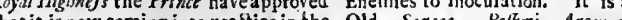
herenf,and that it is now coming into practice in the Old Seneca, Peffmi Argur:entum Turbo eft Nation. In ons of the Publick Prints are thefe For my part 1 th uld be afliamed to joyn with fuch Words, "Inocularing rbe Small Pox. is a fafe and Pertons; 0 niy Soul ccmc. nor sbou tnero sheir Secrer, " univerfally Lfefal Experiment. Several Worthy unro their Aljeanbiy be nor sbou Lnited. I am far Perfons lately arrived from England inform us, that from reflecting upon'all that are againft invo'ericn. it is a fuecelsful Practice there: If Wire \&x learned Men in England, deelare their Approbation of will not he for our Honour.

(witl whom

delire ro Live and Die) that are not clcar in their

Judgnents lor it, and they are grcatly to be commended and honoured in that they will not act

III. GOD has gracioufly owned thePrafice of Ino- againfl a doubting Confclence ; yet it may be fome. culerion, among us in $B o f i c n$, where fomeSeorcs, yea of them might change their minds, if rliey ahove an hundred have been carried; but they BlefsGOD,for His difcovering this them Scriprure Light in this as well as in other Experiment to them. It has been objekted, that one Cafes ol Conficience.

that was Inoculated, died, viz.Mrs. D_ll; but the had the Small $P_{C}$, in the cominon way before, 8 her Friends and nearelt Relations declare that the received no hurt hy Inocularion, but was by a fright put into Fits that caufed her Death. It is then a wonderlul Providence of GOD, that all that were Inoculased thould have their Lives preferved; fo that the Salety and Ufefulnefs of this Experiment is confirmed to us by Oculat Demonftration: I confefs I am afraid, that the Difcouraging of this Practice, may caufe many a Life to be loft, which , for my own parr, I thould he loth to have any hand in, becaufe of the Sixrb Commandmen.

IV. IT cannot be denied but that fome Wife and JudiciousPerfons anong us, approve of lnoculation, both Mlagifiratcs and Miniflers; Among Minifters $1 \mathrm{am} O$ ic, who hive been. a poor Preachet of the Golpel in toffin above Threcfeore Years, and am the molt Aged, Weak and unworthy Minifter now.

Novemb. 20. 172t:

That the Coufe mey buveTwWirnofies bere cre fubjoyned the Sentiments of anober, tell kniwn in our Churcbes, of ubicb I declare my bearry approbusi: $n$. Sentiments on the Small Pox Inoculated.

A mol Surcefsful, and Allizcable Mlebbnd of preA venring Dedth, and many odler grevius lliferies, by the Small Pox, is nor only Lawlul bar a Dury, to be ufed by rboge wbo apprebind rbcir Lie's amme diarely endanger'd by the rerrible Lufen pir.

Bur the Merbod of monoging and grecrning rlse Small Pox in abe way of Inocularion, is a m. It fuc cc/sful and allorible Alicibod of prevenuing Dearh, end many orber grievous Niffrics by rlys dreatlal Diffenper. Therefore, is nor oniy Latwiul, bur aljo

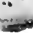

Moved by the Boston epidemic of 1721-1722, Increase and Cotton Mather fought vigorously and successfully for the principle and practice of inoculation for smallpox. 
that we know as portolanos or, in vernacular terms, books of sailing directions, or "pilots." The Portolano Rizo of Venice, 1490, is the Library's earliest book of this type and indeed is the earliest book of the sort ever to be printed. One of the latest in our collection is Lawrence Furlong's American Coast-Pilot of Newburyport, 1796. A recent gift by the Brown University Class of 1880 embodies more than one hundred works on navigation, whaling, shipbuilding, sailmaking, and other sciences, industries, and special skills that go to make up the story of the sea in American life.

The printing of works of a scientific character in Mexico was continuous through the centuries even though of infrequent occurrence. A little more than a decade after the seventeenth century had opened we find current European interests, exemplified in the botanical and pharmaceutical writings of Acosta and Monardes, reflected in America in the publication of an abstract of the work of Francisco Hernández. The Library owns first a manuscript abstract of the Hernández papers made by Nardo Antonio Recchi by command of Philip II, and, following that, the Spanish translation of this abstract printed in Mexico in 1615, and the editions of Hernández published in Europe in 1651 and 1790. Later periods saw the publication in Spanish America of works on metallurgy, mining, mathematics, astronomy, and engineering. Coincident with this local publication appeared European works descriptive of the physical phenomena and natural history of America. A considerable number of these scientific works, both of American and European production, are found in the Library.

In English America the Mathers, John Winthrop, Dr. William Douglass, John Bartram, Mark Catesby, Cad- 
wallader Colden, and, literally, scores of others of the seventeenth and eighteenth centuries pointed the way towards the lively employment of talent and genius in scientific discovery which has dominated the intellectual interests of the United States in later generations. The greatest among the English Americans, of course, was Benjamin Franklin, most of whose works on science are in the collection, and who is represented also by writings of other men which proclaim his influence upon his contemporaries. There are in the collection in considerable number pamphlets relating to plague, pestilence, famine, earthquake, comets, and other large-scale disasters which provide matter of particular interest to the student of scientific thought and illustrate the struggle of the leaders of the period against the practice of interpreting the phenomena of nature in terms of God's anger and vengeance against a sinful world. In this section also are works on birds, insects, reptiles, trees, flowers, agriculture, land surveying, architecture, and numerous other fields in natural history, art, and applied science. There are certainly 1,500 titles in the collection that have a direct interest for the historian of science. If narratives of voyages embodying anthropological and geographical data and observations upon the fauna and flora of new lands were to be included in the numeration, if maps and atlases were counted, and linguistic studies brought within this category, the size of our scientific collection might be stated at a figure three times as great.

\section{Law and Government}

7 HE earliest works in the Library relating to law must be 1 regarded as in the nature of background material inasmuch as they include a considerable number of volumes 
containing laws and ordinances registered by the royal cortes meeting at Toledo, Valladolid, Madrid, and Segovia. Of even earlier date of publication than any of these are the Decretales of Gregory IX, issued in Mainz in 1473, and the Regulae of Sixtus IV, of Strassburg, 1471. Canon law seems somewhat distantly related to our subject, but when we remember the enormous importance of the Church in the life of the Spanish-American countries the presence in our collection of works of this character is not incongruous. Among our manuscripts, indeed, are writings on the canon law by the Bishop Bartolomé de las Casas, Alonso de la Veracruz, Joannes Focher, and others of the fathers of the Church in America. One of the books of special interest in this connection is a celebrated compilation of the thirteenth century in which the Roman law and the canon law were brought together, the Siete Partidas of Alfonso the Wise, represented here in the stately edition of Valladolid, 1587-1588.

The first application to American conditions of Spanish secular law is found in the "Pragmáticas" of Juan Ramírez, published in 1503; from that point onward the collection shows an important group of works relating to the legal aspects of the history of Hispanic America. Notable among these is the volume containing the celebrated laws of Charles $\mathrm{V}$, that is, the Leyes y ordenanças nuevamente hechas, 1543, commonly designated as the "New Laws of the Indies." Following this work of historic interest are various collections of later centuries under titles beginning with such words as "Recopilaciones," "Provisiones," or "Real Ordenanzas." One of these collections, the Provisiones of Diego de Encinas, Madrid, 1596, a work in four folio volumes, has recently been microfilmed at the request 
of a group of scholars who made ten positive copies for distribution among subscribing libraries in Mexico and the United States. Notable in this class also is the Provisiones cedulas, Instruciones de su Magestad of Vasco de Puga, published in Mexico City in 1563, the first code of the secular law of New Spain to be printed. Another distinctive element in this category is a volume in manuscript, written about 1584, containing cedulas from 1522 onwards applying to the operations of the royal hacienda in New Spain. Added to these are some hundreds of royal and viceregal ordinances and cedulas of separate Mexican and Peruvian publication, ranging through every conceivable field of economic, political, and social activity.

The earliest English-American legal document of the collection is Strachey's For the Colony in Virginea Britannia, published in London in 1612, under the harsh provisions of which Sir Thomas Dale and other early governors strictly regulated the colony of Virginia. Those laws, however, were never officially adopted. The New England counterpart of this book, John Cotton's Abstract or the Lawes of New England, long in our collection, likewise was rejected by the Massachusetts General Court as too rigidly following the prescriptions of the Mosaic law. Most of the important volumes of collected laws of later date relating to the English colonies are to be found on the Library's shelves. We do not have the Massachusetts Laws of 1648 , known only by the copy in the Henry E. Huntington Library, but here are both the Cambridge and London editions of the laws of the Bay Colony of 1672, and, more interesting than these from considerations of rarity, the Book of the General Laws of New-Plimouth, of Cambridge, 1672. Following these are the Massachusetts Laws of Boston, 1714, and the chief collec- 


\section{$\mathrm{F} O \mathrm{R}$ \\ The Colony in Virginea BR I T A N I A. \\ Lavves Diuine, Morall and Martiall, orc. \\ Alget qui non Ardet. \\ Res noftra fubinde non funt, qua'cs quis optaret, fedquales effepofjunt.}

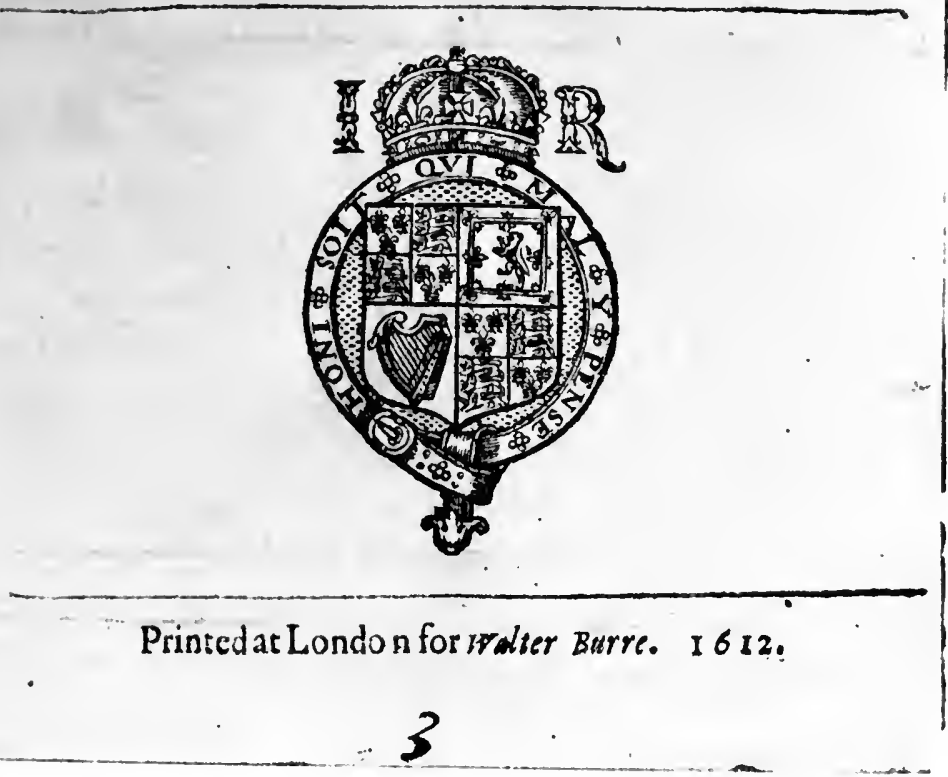

This celebrated code of laws, promulgated by Sir. Thomas Dale for the government of Virginia, restored order in the colony, but becanse of its severity provoked the hatred and execration of the colonists. 

tions of ensuing years. For other parts of the country besides New England the Library owns such well-remembered works as Trott's Laws of the British Plantations in America, 1721 , and all the elements in that series of collected laws relating to the several colonies published by Baskett in London in the period 1719 to 1727. A few of the notable volumes of local publication in the collection are Trott's Laws of South Carolina, 1736; the Parks editions of the laws of Maryland, 1727, and of Virginia, 1733; Bacon's laws of Maryland, 1765; the Andrew Bradford edition of Pennsylvania laws, 1714, and other Pennsylvania collections printed by Franklin and various Philadelphia establishments; and the collections of New York laws brought out by William Bradford in 1726 and James Parker in 1752.

In addition to these there are collections proceeding from the English colonies in the West Indies and from Canada < and Nova Scotia.

In our section on New France and Louisiana we have mentioned among our resources relating to the French in America the 350 or more separately printed royal édits, arrêts, and ordonnances proclaimed from time to time for the government of the colonies in Canada and the West Indies. This respectable group is made a truly rich resource through the presence in the Library of such works as $L e$ Code Noir, Le Commerce de l'Amérique par Marseille, Mémoires des Commissaires $d u$ Roi, and three or four other recueils of French administrative acts of a general and specific character. In the contents of these collections we have access to some thousands of the royal pronouncements through which the government of the French colonies was carried on in the seventeenth and eighteenth centuries. 


\section{Bibliography}

T $^{\mathrm{T}}$ probably has been made sufficiently clear that the 1 Library relies entirely upon the Library of Brown University for works printed after the year 1800 , no matter how closely related they may be to the interests of the earlier period. For example, collections of documents pertaining to events of the seventeenth or eighteenth centuries but edited and printed in the nineteenth or twentieth centuries would normally be found in the John Hay Library. Historical studies of the events of the colonial period written and published in the nineteenth and twentieth centuries are also located in the general library of the University. The case is different, however, when it is a question of the closely related category of bibliographical studies and catalogues of early source materials. On our shelves is to be found a collection of some four thousand titles comprising many hundreds of bibliographical monographs on single books, single authors, and the production of individual printers as well as copies of the large national bibliographies-Evans's American Bibliography, Sabin's Dictionary of American Books, and the works of José Toribio Medina on Mexico, Peru, Chile, and numerous smaller Hispanic-American divisions. No description of the collection is necessary beyond what has been given except to say that a large number of its titles are in the form of monographs and of authors' separates of articles first published in periodicals, the sort of material which too often is regarded as ephemeral and not suitable for permanent preservation. Another thing that might be said of this collection is that a strikingly large number of its titles are works of the last forty or fifty years 


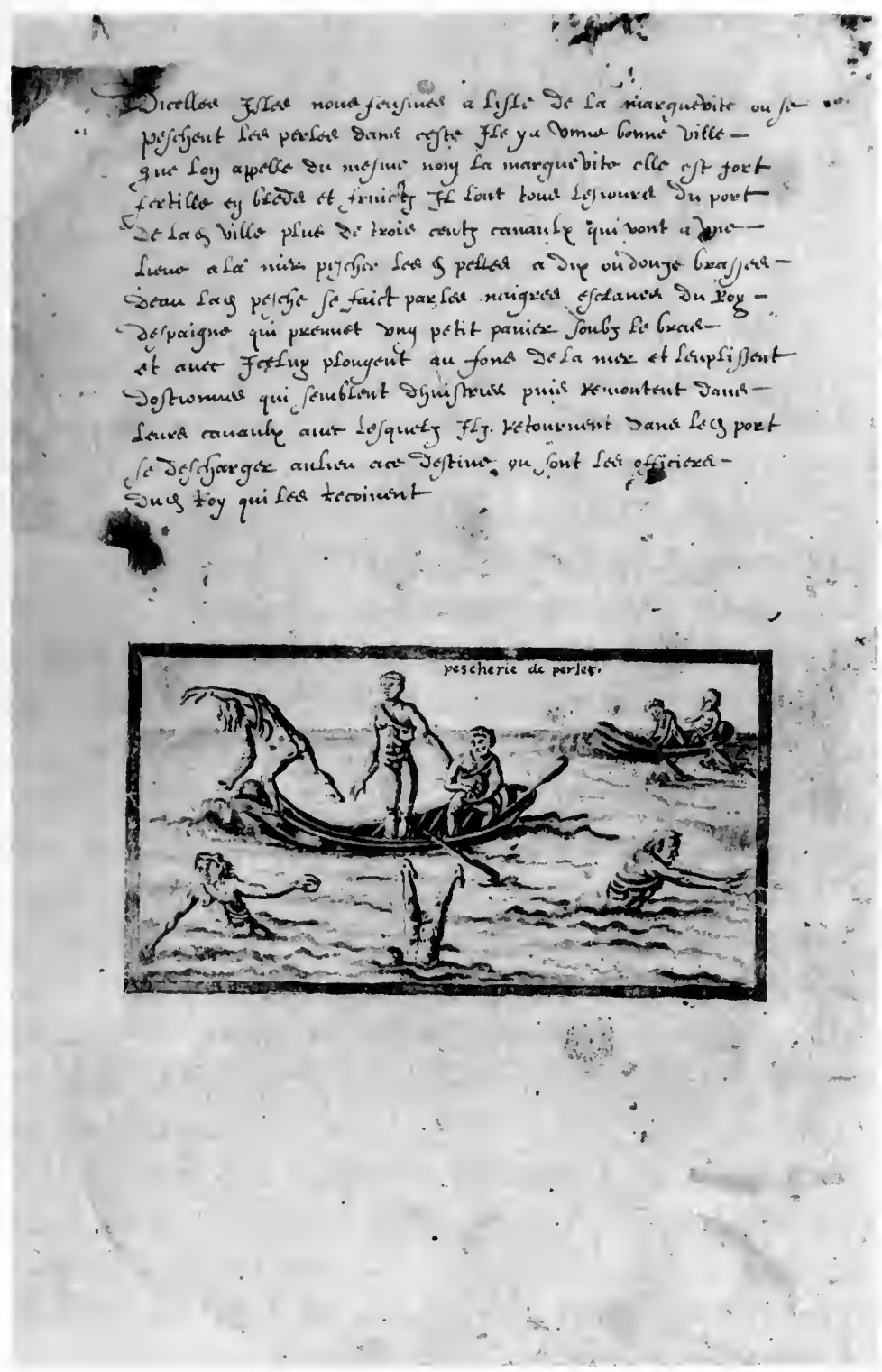

Distinguished among original manuscripts of American interest is Samuel de Champlain's journal, beautifully illustrated in water color, of his voyage to the West Indies in the years 1599-1601. 

composed, in some part certainly, through the aid of original source materials found upon our shelves.

\section{The Manuscript Collections of American Source Materials}

7 Hovgr the professed policy of the Library confines its 1 purchases to printed materials, it is inevitable that in a century of collecting many manuscripts also should have found their way into our hands. Some of these have drifted in, so to speak, others have been acquired by purchase in what may seem to have been disregard of the rules. But these rules, fortunately, lend themselves to a liberal and sensible interpretation. Groups of autograph letters by many different hands, or collections of documents on unrelated subjects may properly be regarded as archival material and therefore outside our field of collecting. On the other hand, in our conception, a treatise or a compilation on a single subject is a book whether it is set forth by hand or in print. Manuscript books of this description predominate in our collection in the section devoted to Indian linguistics, in which, as already related, are found fifty manuscript dictionaries, grammars, and texts of the first interest to students of the subject.

A manuscript of a different sort from those of linguistic character, and an item of high renown among Americanists, is the journal of a voyage to the Spanish Indies made by $<$ Samuel de Champlain in the period 1599-1601. There is here, also, a manuscript treatise on geography by Henricus Glareanus, and three manuscript atlases, as well as a number of separate manuscript maps of different periods. Bishop Las Casas, Fray Alonso de la Veracruz, Francisco Hernán- 
dez, Bernardino Sahagún, Joannes Focher, López de Velasco, and Archbishop Zumárraga are represented by works in manuscript of a theological, canonical, or scientific character, nearly always with an American application. Pedro Font's Diario of the expedition which settled San Francisco is one of our acknowledged treasures. One group of manuscripts of large potential interest, embodied in fourteen folio volumes, comprises thousands of documents in the form of certificates and affidavits by some 1,500 novitiates of the Franciscan province of Santo Evangelio of Mexico. There are here also three folio volumes containing $153 \mathrm{docu}-$ ments and groups of documents, chiefly in contemporary official copies connected with Mexican political and administrative affairs of the period 1588-1745, many of them relating to Florida and the Spanish Southwest of the United States. A calendar of this group of papers, compiled by Father Damian van den Eynde, was published in 1936 in the Hispanic American Historical Review. The manuscript versions of Mexican ecclesiastical chronicles-those of Father Beaumont on the Franciscan province of St. Peter and St. Paul of Michoacán, and Father Tello on the province of Xaliscoare among the Library's most interesting possessions. A volume of royal cedulas, previously mentioned, relating to Mexico, compiled about 1584 and beginning with a document of 1522, is likewise to be found in the collection, while scattered through the Library are a number of individual petitions and memorials and numerous documents concerned with the military, commercial, and fiscal affairs of New Spain. Other notable single manuscript pieces in the Library are a contemporary abstract of the Columbus Book of Privileges, the document signed by Bishop Zumárraga establishing the archbishopric of Mexico, an early transcript 


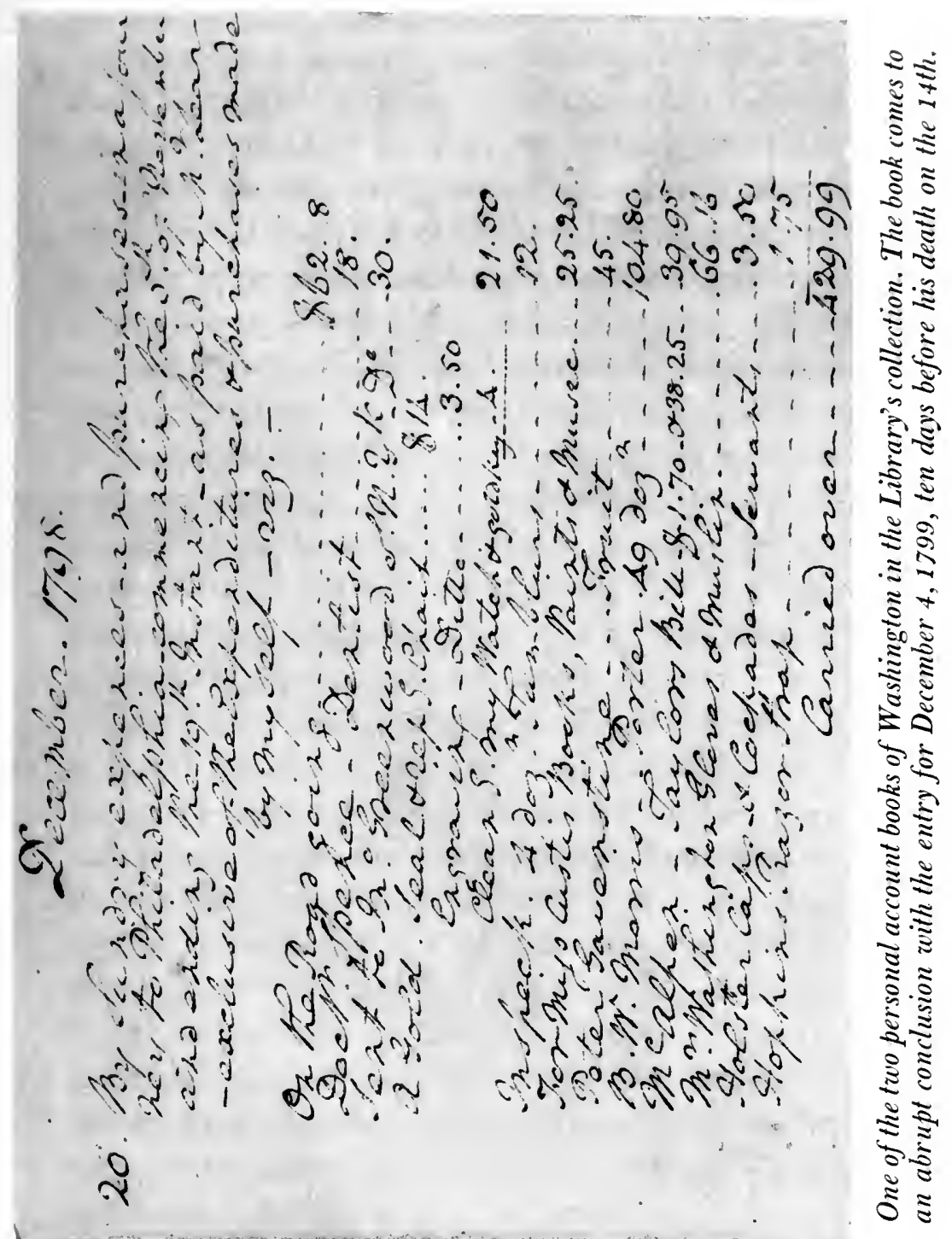



of the lost Cortés journal of the expedition to Honduras in 1524, an Aztec document in the form of a painted book written and illustrated about the year 1550, and, to bring the list to a close, a seventeenth-century manuscript of the Las Casas Historia de las Indias, one of the earliest known texts of a great work which was not published in print until 1875 .

Hardly less interesting are our manuscripts relating to the history of English America. One finds here the volume previously spoken of containing the official papers of Lord Chancellor Hyde and certain of his descendants, covering colonial matters of the period 1660-1768; a collection of nineteenth-century transcripts of materials in England and America relating to Rhode Island in the period before 1801; duplicate contemporary communications from the Privy Council to the governors of Rhode Island in the period 1740-1769; the five volumes of letters, already described, written from the Bahamas to George Chalmers, agent of the colony in England; several hundred letters and documents of colonial worthies, including a collection of the Signers of the Declaration of Independence; a volume containing fifty-one letters from George Washington to Joseph Reed; and, in some senses the most cherished of our possessions, the last two personal account books kept by Washington, the entries beginning in 1794 and ending in 1799, a few days before the onset of his fatal illness.

The largest and most unusual collection of manuscript materials in the Library is that known as the Brown Papers, which we have described in an earlier section relating to our economic resources. There is in the Library also a group of manuscripts of a later date in the form of the public papers of John Russell Bartlett, John Carter Brown's friend and librarian. Notable among these are the eleven volumes of 
journal and correspondence proceeding from the years of Mr. Bartlett's service as United States Commissioner for running the Mexican boundary under the Treaty of Guadalupe-Hidalgo.

Illuminated Manuscripts, Incunabula, Bibles, Aldines, and other non-American Collections

7 HROUGH the interest of the former private owners of the 1 Library in fields outside Americana, a number of extraordinarily fine single pieces and groups of little or no direct American interest are on our shelves. Despite their general character, however, these pieces contribute in many ways to the usefulness of the institution. Foremost among them are the seven illuminated manuscripts acquired by Mrs. John Carter Brown after the death of her husband in 1874, and previously mentioned as elements in the background of the Discovery Period. The earliest of these is a missal and gradual of the twelfth century, proceeding from the Benedictine Monastery of Ottobeuren in Swabia, a manuscript of high interest from the standpoints of liturgics, musicology, decoration, and handwriting. The latest is an Italian Psalter of about 1540 representative of the best workmanship of a more sophisticated period. Between these are five distinguished examples of French, Spanish, Flemish, and Italian illuminated manuscripts. Mrs. Brown purchased for the family library, also, copies of the four Shakespeare folios, the first, of 1623 , being in many respects of size and condition the finest of all recorded copies of that great book. To these were added by Mrs. Brown and her son John Nicholas several notable specimens of books printed in the fifteenth century-the Gutenberg Catholicon, the Boccaccio of Colard Mansion of Bruges, 1476, and the 
Caxton Royal Book of 1484. Harold Brown acquired the magnificent Bible of 1462 in a copy printed on vellum, formerly owned by Prince Eugene of Savoy. All these except the Caxton are fine copies in perfect condition. John Carter Brown brought together in the early years of his collecting about 300 Aldines, a collection previously mentioned as providing the important classical ingredient in the Renaissance background of modern civilization. In the same period he bought splendid copies of the five great polyglot Bibles, those of Alcalá de Henares, Antwerp, Nuremberg, Paris, and London.

To these non-American collections have been added from time to time by gift a number of rare incunabula and Bibles of special typographical quality. Because of its interest in the press as an important factor in social history, the Library has developed through the years a subsidiary interest in the history and art of the book. The manuscripts and monuments of typography here mentioned have contributed sensibly to our maintenance and development of this interest. 



\section{Part III}

The Work of the Library 



\section{The Work of the Library}

$\mathrm{TT}^{\mathrm{T}}$ is the natural thing for one who has read the foregoing

1 account of the Library and its collections to ask us what we are doing with this wealth of material, brought together at considerable cost in terms of money and at a great expenditure of effort. The answer to the question in general terms is that we are administering it for the benefit of the world of scholarship. A more specific answer, and one which the question plainly deserves, takes the form of an account of the work of the Library set forth under the following heads:

(a) the bibliographical study of the collections

(b) service to local and visiting students

(c) correspondence with distant students

(d) exhibitions and addresses

(e) publication and photographic service

(a) The bibliographical study of the collections

The Library's ideal is to secure every edition and issue of every book within its field. This is not mere acquisitiveness; we regard each of these issues as a stage in the history of the book and the book as an element in the history of the subject it represents. We know that the proper use of a text by a scholar necessitates a complete knowledge of the history of that text in all its variations. A book is a creation of the human spirit, and the reflective scholar, as distinguished from the industrious collector of facts, wants to know what circumstances brought it into being, what shapes and forms that creation has taken, what evolution its matter has undergone, what has been its influence upon its own and later times. To assist him in determining these factors is, in our conviction, the reason for being of the science of bibliography. Bibliography may be, and often is, practised as an 
end in itself; in our belief and practice it is a process in the study of texts, and a text is a creation of the spirit of man in its struggle to be heard and understood. So considered, bibliography becomes a living science important in the prosecution of humane studies.

Holding these beliefs, we resort to various practical means of making them effective. We have in constant process of formation and revision an author-title-subject catalogue of the sort found in every library and, believing that any period of time- - a year, ten years, or a century - is best studied through the printed product of that period, we have formed also a catalogue in which every book in the Library is entered under the year of its publication. The student of the American Revolution, for example, must know the ideas current in the years immediately preceding it. Entries in our chronological catalogue for the period 1764-1774 present him with a picture of ideas and movements as they developed throughout that period. Because of this and other uses to which it may be put, this chronological conspectus of the thought and action of any period in American history becomes in itself a source for the study of that period, a source all the more effective in that, embodying the productions of European as well as American writers, it establishes parallel relationships between the affairs of British, French, and Spanish America and the affairs of Europe of the same period.

Another currently maintained catalogue in the Library is that which we call our Bibliographical File, a file chronologically arranged in which we record every bit of information about a book discovered in the course of our daily work or conveyed to us by visitors or correspondents. As it grows in extent that file becomes increasingly important in our work. 
Other special catalogues are maintained by us in defiance of the ideal currently held which demands the consolidation of all lists and files into the single general catalogue of the institution. But one must go by his own experience, and we have learned in this Library that we are able to give quick service and comprehensive information to our visitors by the use of the following separately maintained catalogues:

(1) the chronological list already described;

(2) a catalogue of bibliographical works relating to America;

(3) names of the printers, publishers, and engravers responsible for the production of the books, prints, and maps in the Library, and, in addition, the names of the places of publication of these items;

(4) a catalogue of maps arranged by place delineated;

(5) a list of portrait subjects in books or in separate prints;

(6) a list of book-plates in our volumes;

(7) a list of autographs of former owners.

In addition to these catalogues maintained in the building for the use of research workers and our own staff, we have supplied cards containing all our titles for inclusion in the union catalogue in the Brown University Library and the Union Catalogue of the Library of Congress. In 1919 we began the publication of a printed catalogue of the entire collection, which cost of production compelled us to discontinue upon the appearance of Volume III in 1931. Plans are in the making for resuming this publication in a form which we believe will be greatly more effective, that is, as the basis of a union catalogue of eighteenth-century Americana contributed to by twenty or more leading libraries of the country. 
(b) Service to local and visiting students

Every student of whose serious purpose we are assured is allowed access to the resources of the Library. We make no distinction as to scholastic grade, welcoming undergraduates vouched for by an instructor, and we lay down no conditions of use except to require that in the publication of unique materials our Committee of Management be assured that the editing will be scholarly and the form dignified.

The Library feels that its highest form of usefulness is to put the scholar directly into contact with the prime'materials upon which his work depends. The annual average of visitors to the building for research purposes in the fiveyear term 1937-1941 was 761, a number nearly twice as large as that for 1930-1934, and more than three times that for the term 1925-1929. This steady growth in the utilization by students of our varied resources is one of the more solid of our several grounds for encouragement. Our research visitors are in many cases graduate students of Brown or of other universities in various parts of the country; others of them are mature historical workers drawn hither from many places through the knowledge of almost certain helpfulness to be received from our collections.

\section{(c) Service through correspondence with distant students}

In the past ten years the Library staff has written each year an average of about 800 letters on bibliographical or historical topics. Most of these were in reply to inquiries received from scholars and bookmen resident in England or on the Continent, in Canada, Mexico, and South America, on our own Pacific Coast, in the far Southwest, Florida, and other sections of the country. A good number of our inquiries in this period, as always in the past, came from book- 
sellers in various parts of the country. We are particularly proud of our long coöperation, our continuous exchange of information and services with booksellers. We like booksellers, and we believe most firmly that good booksellers make good libraries. The remainder of our outgoing letters were written on our own initiative in search of information for our files, or when, learning of work in progress elsewhere, we have volunteered what seemed to us information pertinent to its ends. This sort of pump-priming seems to us legitimate.

\section{(d) Exhibitions and addresses}

The Library attempts a service to the general university and civic community of which it is a part by putting on each year about four long-term exhibitions and, between times, a number of smaller displays of material assembled at the request of members of the faculty for instruction purposes. The exhibitions are taken seriously by the staff as one of the Library's chief opportunities to interest its local community, and the effort is made to have each one tell a story to the visitor as well as display to him the Library's resources. During the past six or seven years there have been certain of our exhibitions which we feel were of particular importance, notably those on the Constitution of the United States, the Opening of the Northwest Territory, the Settlement of New Sweden on the Delaware, the History of Printing in Mexico and the British American Colonies, the Mapping of the World, 1410-1774, the American Tradition, the Mapping of the Pacific and Indian Oceans, and, most recently, Three Centuries of Canadian History, 14981800. Most of these were put on to mark anniversaries nationally observed. The minor exhibitions, assembled gener- 
ally by request of members of the faculty, were made up of material chosen to illustrate talks given to classes of undergraduates by their instructors or by someone upon the staff of the Library. Each year sees a number of professors taking advantage of the Library's ability to coöperate in their teaching of history, literature, the classics, and the minor arts.

\section{(e) Publication and photographic service}

Because of its small staff the Library has never been able to maintain a regular series of publications. In this particular, however, as in others, it does what it can, believing firmly that a small contribution of important matter is better than none at all. Every year in October it presents to the Corporation of Brown University, and afterwards publishes, an annual report in which the effort is made to explain the character of its operations in the preceding year and the significance of its acquisitions, relating the books secured to the development of America and to life in general. The idea that an Americana collection is something esoteric, appealing only to those who live in the thin atmosphere of the upper strata of scholarship, is countered with determination in this discussion of the materials we add each year to our great collection. The Library staff is now editing for publication an index to the Report for the period 19111945, which has been prepared by Miss Miriam Lone, of New York.

Occasionally a monograph or a facsimile of a rare piece is issued by the Library for general sale or free distribution. In the past three years, for example, we have published collotype reproductions of the Augustine Herrman map, Virginia and Maryland, published in London in 1673 and known 
today only by our copy and the copy in the British Museum; the Cyprian Southack chart of the English empire in North America; and the Map of the South and east bounds of Pennsylvania in America, the first map of Pennsylvania, published by William Penn in 1681 as an element in promoting the settlement of his new colony. Our chief method of publication, however, is through the medium of the photostat camera. Through the foresightedness of a former librarian, George Parker Winship, the Library became as long ago as 1912 one of the pioneers in the use of the photostat for research and publication purposes. Our copying for twelve subscribing libraries of a file, as complete as could be assembled, of the Newport Mercury for the years 1758-1800 was the earliest large-scale publication of that sort undertaken by an American library. In 1941 we reproduced for nine libraries the eighteenth-century manuscript of our French and Miami-Illinois Indian dictionary and, for a somewhat smaller number, the sixteenth-century manuscript of our Motul-Maya dictionary. Since the institution in 1919 of its series of photostat reproductions made for fifteen subscribing libraries, the Massachusetts Historical Society has issued in facsimile forty-four books and pamphlets from our collection, about ten per cent of the two series lately completed. If we consider the reproduction of a single copy of a book, or of a portion of a book, to be a species of publication it will be seen that our annual publishing program is extensive, for in addition to photostat orders received from individuals in the last pre-war year we copied books or parts of books for twenty-one university and historical society libraries in seventeen states of the Union. There are few important libraries in the country which do not have on their shelves one or more photostat reproductions of rare 
books in our collection made in our own photographic department. In a normal year we make 4,000 photostat prints from books and manuscripts in the Library, and, through the Brown University Photographic Laboratory, some thousands of microfilm exposures. The photostat and microfilm cameras have been most important agencies in the Library's service to the historian and to the private and institutional collector.

In 1940 Brown University received from the Rockefeller Foundation a substantial grant to be employed in microfilming historical source materials of Latin-American interest not already available in the libraries of the United States. The first stage in that project was completed in 1943 with the receipt by the University of microfilm copies of 2,376 books made by its field agent in the great Latin-American library of José Toribio Medina, now owned by the Biblioteca Nacional of Santiago de Chile. These films must be regarded as an extensive and valuable supplement to the original materials in the John Carter Brown Library and in the George Earl Church Collection of the John Hay Library. The University is prepared to make copies at small cost from its master films of any or all of these books for other libraries or individual students interested in procuring them.

\section{Conclusion}

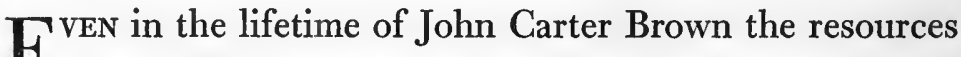
1 of the Library were being made available to American historians when other collections of Americana were either too closely guarded by their owners, or for some other reason were unavailable for consultation. In later years, the appointment of a librarian was forced upon John Nicholas 
Brown by the many requests he received for permission to use the collection. In the forty-five years of its present ownership the utilization of the Library's resources by American and foreign scholars has steadily increased. It is not, however, the annual number of research visits received, or the number of inquiries answered, to which we call attention so much as the continuity of our service. Some hundreds of research visits and an equal number of letters each year multiplied by forty-five years means a wide dissemination of influence. Several thousand photostat prints a year multiplied by the thirty-three years of our possession of a camera means that the materials of this Library have aided a very large number of distant students.

Another interesting sum in multiplication could be done if we had the correct figure for the multiplicand throughout the period, that is, the number of new productions annually received of a literary or historical character in the form of separate or periodical publications which were based in whole or in part upon our materials. In the past twenty years, thirty-five such books and articles have been received annually. Our own reference shelves are crowded with books and monographs of this character which are of daily usefulness in our work and in the research of our visitors and correspondents. With such evidence surrounding us we are justified in feeling that the collection has made impact upon the study of history in our times.

Perhaps this account of the John Carter Brown Library should come to a close upon a note of humility. There has been little of that in what has been written, for we are unashamedly proud of the achievement of the founders of the institution, and that pride makes itself felt whenever the 
staff or the members of the Committee of Management talk about the Library. But even while acclaiming our age and long tradition, while enumerating our possessions or boasting our strength in one or another category, we still hold heartily to the conviction that without service all these things are vanity. Written deep in our consciousness is the solemn admonition of the poet who said:

"Now understand me well-it is provided in the essence of things that from any fruition of success, no matter what, shall come forth something to make a greater struggle necessary."

At the beginning of its second century, the John Carter Brown Library is settling into its stride. 





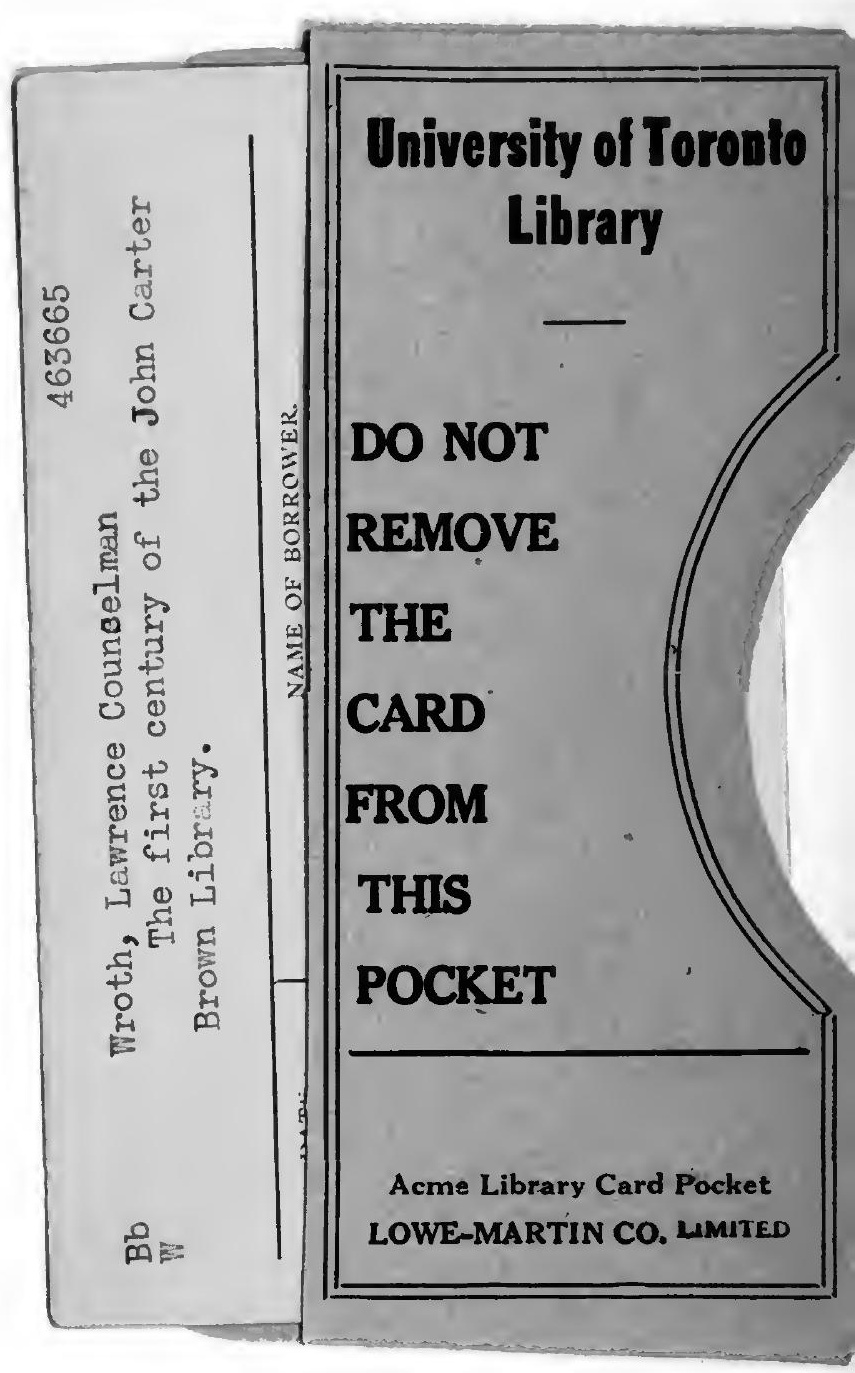


. 